I NTER NATIONAL MONETARY FUND

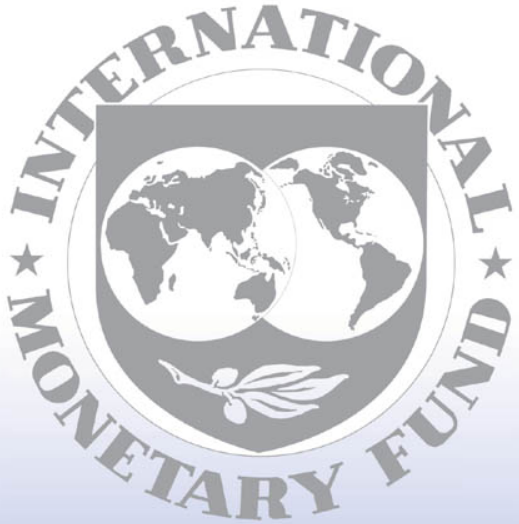

Staff

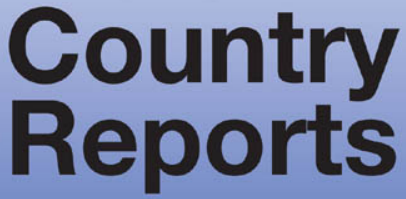




\section{Lebanon: Selected Issues}

The Selected Issues Paper on Lebanon was prepared by a staff team of the International Monetary Fund as background documentation for the periodic consultation with the member country. It is based on the information available at the time it was completed on January 10, 2012. The views expressed in this document are those of the staff team and do not necessarily reflect the views of the government of Lebanon or the Executive Board of the IMF.

The policy of publication of staff reports and other documents by the IMF allows for the deletion of market-sensitive information.

Copies of this report are available to the public from

International Monetary Fund $\bullet$ Publication Services

$70019^{\text {th }}$ Street, N.W. • Washington, D.C. 20431

Telephone: (202) 623-7430 • Telefax: (202) 623-7201

E-mail: publications@imf.org Internet: http://www.imf.org

\section{International Monetary Fund \\ Washington, D.C.}


This page intentionally left blank

CInternational Monetary Fund. Not for Redistribution 


\section{LEBANON}

\section{Selected Issues}

Prepared by Azim Sadikov, Annette Kyobe, Najla Nakhle (all MCD), and Asmaa El-Ganainy (FAD) Approved by the Middle East and Central Asia Department January 10,2012

I. Private Sector Credit Growth in Lebanon-Supply or Demand Driven?

A. The Credit Surge. $\underline{4}$

B. A Disequilibrium Model of the Credit Market: Is the Credit Surge Supply or Demand Driven or Both?

C. Conclusion

References

Tables

1. Growth of Credit to the Private Sector in US\$, 2008-10.....

2. Maximum Likelihood Estimation of Disequilibrium Model

Figures

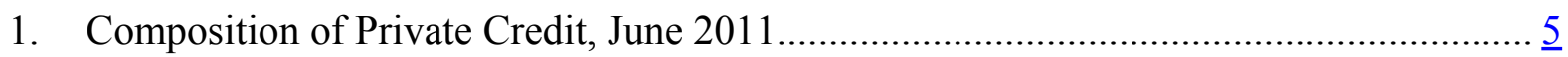

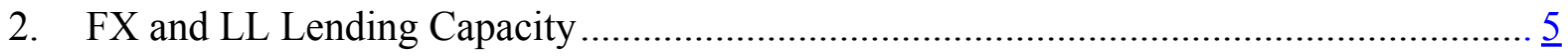

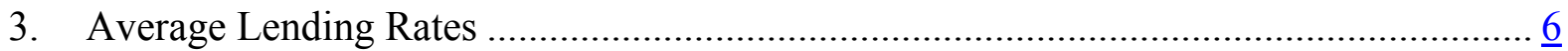

4. Share of LL and FX Lending in New Credit Over the Past 12 Months ........................... $\underline{6}$

5. Loans Benefiting from 2009 RR Exemptions and Their Share of Total Loans ................. 7

6. Housing Loans Benefiting from 2009 RR Exemptions and Their Share of Total Loans.. $\underline{7}$

7. Predicted Supply, Demand and Actual Credit, 1997-2001 ……................................. 12

8. Deviation of Supply and Demand from Actual Credit Volume, 1997-2001 ................... 12

Appendix Tables

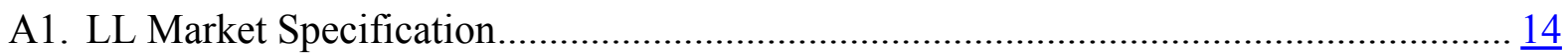

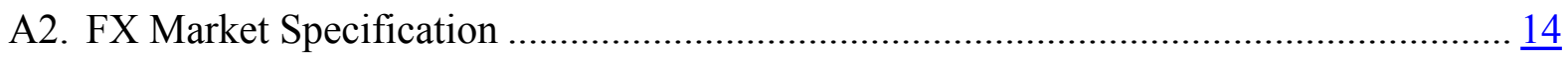


II. The Price of Oil and the Lebanese Economy: A Blessing in Disguise? ............................. 16
A. Transmission Channels
$\frac{16}{18}$
B. Impulse Response Functions ………………………........................................ $\frac{18}{20}$
C. Long-Run Relationship in a VEC Model .............................................................. $\frac{20}{20}$

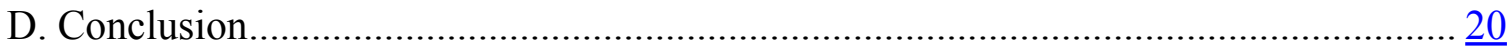

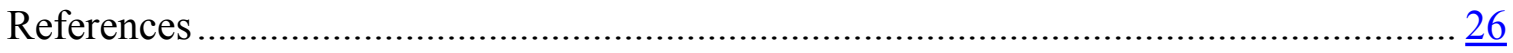

Tables

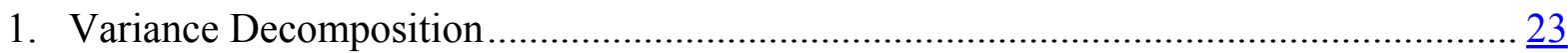

2. Vector Error-Correction Model ……………......................................................... 24

Figure

1. Orthogonalized Impulse-Response Functions to a Positive One-Standard

Deviation Oil Price Innovation

Appendix $\underline{25}$

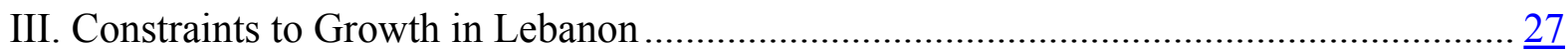
A. Is it High Cost of Finance?
B. Is it Low Returns to Economic Activity?
C. Conclusion
References

Table

1. Real GDP Growth, 2000-10: Average and Standard Deviation.

Figures

1. Real GDP Growth $\underline{27}$

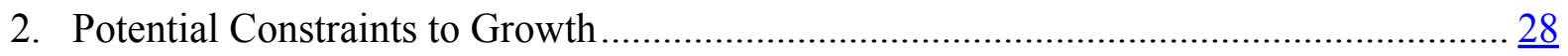

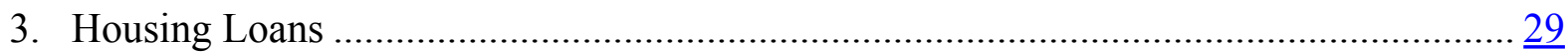

4. Political Risk Rating in MENA Countries, August 2011 .............................................. $\underline{31}$

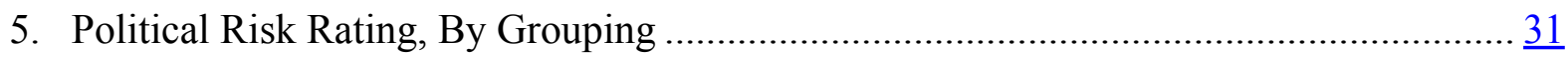

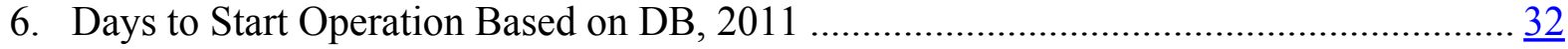

7. Days to Get Operating License (Firm Level) in MENA …………................................... $\frac{33}{33}$

8. MENA Countries Average Percentile Rank on World Governance Indicators, 2009...... $\underline{33}$

9. Real Growth Rates and Public Debt Levels ..............................................................

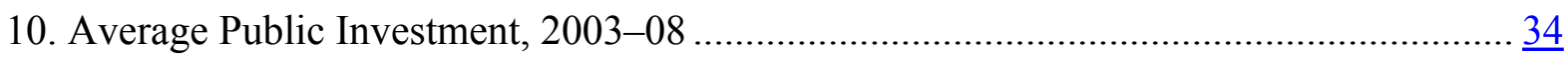

11. Public Investment in Lebanon, 1990-2009 ................................................................

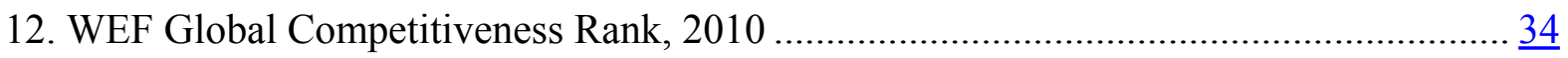


IV. Poverty, Social Safety Net, and Subsidies in Lebanon.................................................... $\frac{37}{38}$

A. Lebanon's Social Safety Net and Subsidies............................................................. $\frac{38}{41}$

B. Weaknesses in the Social Safety Net and Subsidies ………...................................... $\frac{41}{44}$

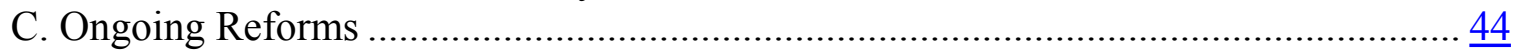

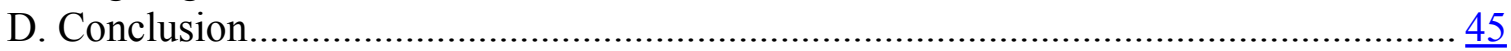

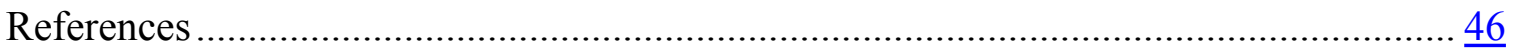

Tables

1. Gini Index and Income Shares Held by the Poorest and Richest Quintiles (In Percent) In Selected MENA Countries, Various Years .............................................................. $\frac{37}{38}$

2. Cost of Social Safety Nets and Various Subsidy Schemes, 2010 .................................. $\underline{38}$

Figures

1. Distribution of Poverty and Extreme Poverty by Region, 2004 ..................................... $\frac{37}{38}$

2. Evolution of Social Spending, and EdL Subsidies, 2004-10 ....................................... $\underline{38}$

3. Social Safety Net Expenditures in Selected MENA Countries, Various Years ................ $\underline{39}$

4. Fuel/Energy Subsidies in Selected MENA Oil Importing Countries, 2010 ...................... $\underline{39}$

5. Distribution of Subsidies Across Income Groups......................................................... 41

Boxes

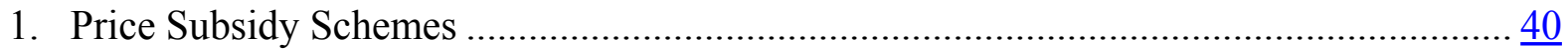

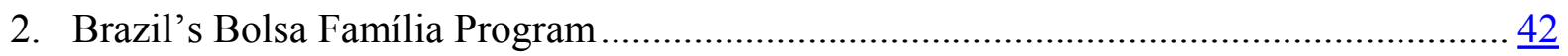




\section{Private Sector Credit Growth in Lebanon—Supply OR Demand Driven? ${ }^{1}$}

Credit to the private sector surged in Lebanon during 2008-10 with credit in local currency (LL) expanding about twice as rapidly as foreign currency $(F X)$ credit. Using a disequilibrium model of the credit market, we investigate if the surge was driven by supply or demand. Results suggest that credit growth was primarily supply driven, fueled by large deposit inflows and positive economic prospects. Banque du Liban (BdL)'s subsidy schemes also appear to have encouraged lending in Lebanese pounds.

\section{The 2008-09 financial crisis led to a sharp pullback of private credit in many} countries. Even as economies started to recover in 2009, credit remained weak as banks tightened lending practices to reduce risks, maintain high liquidity, and clean up their balance sheets. At the same time, households and businesses have continued to de-leverage given their high indebtedness and the uncertain outlook.

2. In contrast, credit surged in Lebanon, from an already higher base than the median in comparator countries. Credit growth slowed briefly at the height of the global crisis, but rebounded by mid-2009 (Table 1). Private sector credit growth was almost 20 percent per year during 2008-10, much higher than the average 6 percent per year during 2005-07. And in October 2010, banks' lending to the private sector overtook public sector lending for the first time since 2005.

\section{This note looks at what caused the credit surge and determines to what extent it reflects strong demand or an increase in credit supply.}

\section{A. The Credit Surge}

4. Credit growth in 2008-10 was concentrated in trade and services, household loans, ${ }^{2}$ and the construction sector. These sectors accounted for almost 80 percent of all new loans extended since 2008 (Figure 1). Real estate lending in particular increased substantially. In parallel, lending to nonresidents has been growing rapidly, reflecting the strategy of Lebanese banks to expand in the region. Nonresident loans, including those to

\footnotetext{
${ }^{1}$ Annette Kyobe, Najla Nakhle, and Azim Sadikov.

${ }^{2}$ Household loans are for consumption, education, cars, and mortgages.
} 
bank affiliates abroad, made up 13 percent of total private sector loans at end-2010 and grew by 16 percent over the same period. Although about three quarters of loans are in FX, LL credit has grown faster than FX credit in recent years. Since 2008, LL credit grew 35 percent annually and FX 16 percent, compared to 5 percent for both LL and FX during 2005-07. While credit growth has fallen since January 2011, reflecting the downturn in the economy and a cooling in the real estate market, ${ }^{3}$ it remained strong at 15 percent y-o-y at end-September 2011.

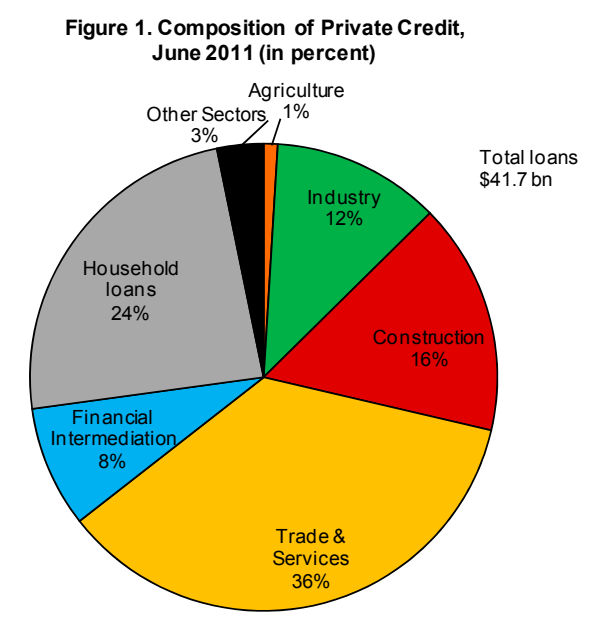

Sources: Banque du Liban; and IMF staff estimates.

5. A number of factors could have contributed to the credit surge. On the demand side, a renewal in confidence following an improved political environment in 2008 led to a rebound in economic activity, which together with a real estate boom fueled credit demand. On the supply side, the interest differential between high domestic and low global interest rates led to large deposit inflows. This increased domestic liquidity and, in turn, lending capacity (measured as deposits less the sum of banks' required reserves and their holdings of government and central bank securities).

\section{The Banque du Liban (BdL) reduced reserve requirements to encourage lending} in pounds. Pound lending capacity declined in 2007-09 reflecting a surge in banks' investment in high-yielding BdL Certificates of Deposit (CDs) and government T-bills (Figure 2). But the decline in yields on CDs and T-bills starting in 2009 (Figure 3) reduced interest margins, prompting banks to seek alternative sources of income. Banks thus started to increase pound lending to the private sector. This was further encouraged by incentives, introduced by the BdL in June 2009, which reduced

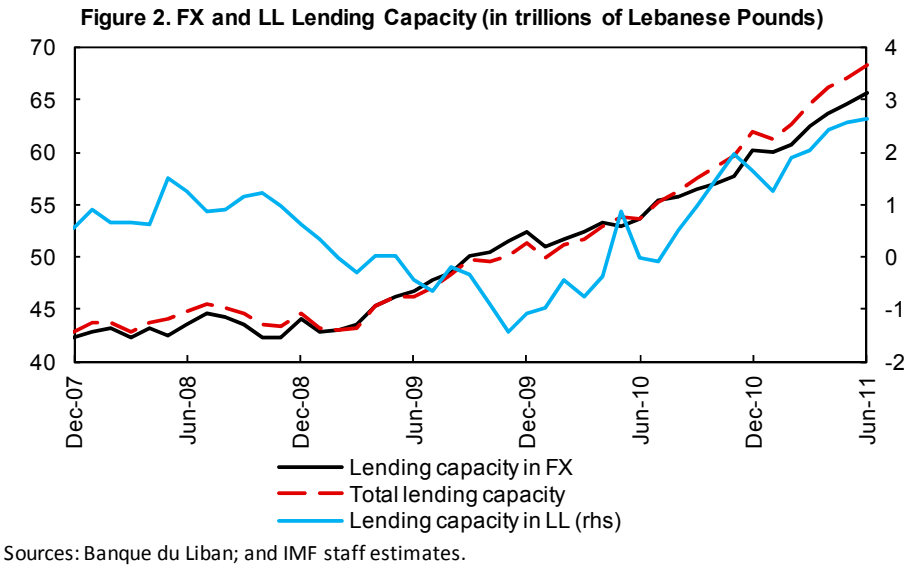
effective reserve requirements if banks extended loans to certain sectors. These incentives were on top of existing schemes: an interest rate subsidy scheme for medium- and long-term

\footnotetext{
${ }^{3}$ Housing prices increased by 183 percent during $2005-10$, but are now $10-15$ percent off their peaks.
} 
loans launched in 1997; Kafalat, a non-profit partial credit guarantee fund established in 2000 , that guarantees credit targeted mainly to industry, agriculture, IT and tourism; and reductions in reserve requirements, first started in 2001. Additional reserve requirement exemptions introduced in 2009 allowed banks to deduct $60-100$ percent of a qualifying loan in LL (depending on the type of loan) ${ }^{4}$ from required reserves on customer deposits, up to a ceiling of 75 percent of the reserve requirement for all qualifying loans. With banks reaching this ceiling, the BdL widened the ceiling to 90 percent of the reserve requirement in January 2011.

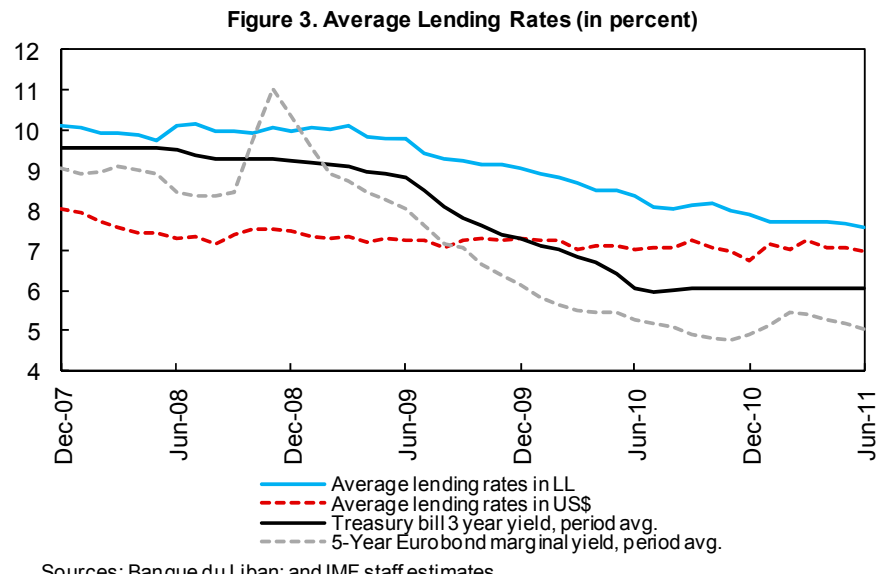

Sources: Banque du Liban; and IMF staff estimates.

\section{The schemes to reduce} effective reserve requirements helped accelerate pound credit. Reducing required reserves frees up funds available for lending and lowers banks' costs, which they can pass on to borrowers. While the share of LL lending in total new credit started to pick up at end2008 , it accelerated with the introduction of the 2009 schemes (Figure 4). The share of LL lending

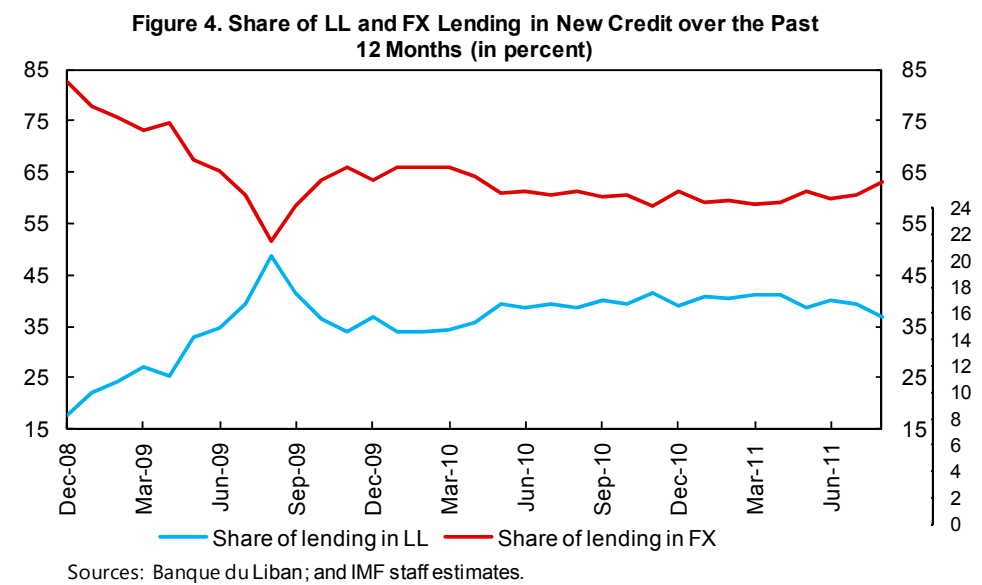

—Housing loans benefiting from exemptions prior 2009 (in billion US $\$$ ) Share of housing loans benefiting from 2009 RR exemptions in all housing loans (in
percent, rhs)

in new lending increased from 16 percent to nearly 40 percent by end-2010. Loans falling under the 2009 schemes grew rapidly, contributing more than half of the growth of loans benefiting from all exemptions (Figure 5), with housing loans growing particularly fast (Figure 6). Total loans under various schemes now account for 13 percent of private sector loans. Because only loans in LL qualify, the schemes help prevent a build-up of FX exposure (most borrowers are unhedged) and encourage loan dedollarization.

\footnotetext{
${ }^{4}$ During June 2009-August 2011, there were about \$1.1 billion in housing loans and \$59 million in new education loans; in addition, there were loans to environment friendly projects and small and medium enterprises. Real estate development and consumption-related lending do not qualify. Education loans qualify for a 100 percent reduction, housing for 65 percent and housing loans to military for 60 percent.
} 

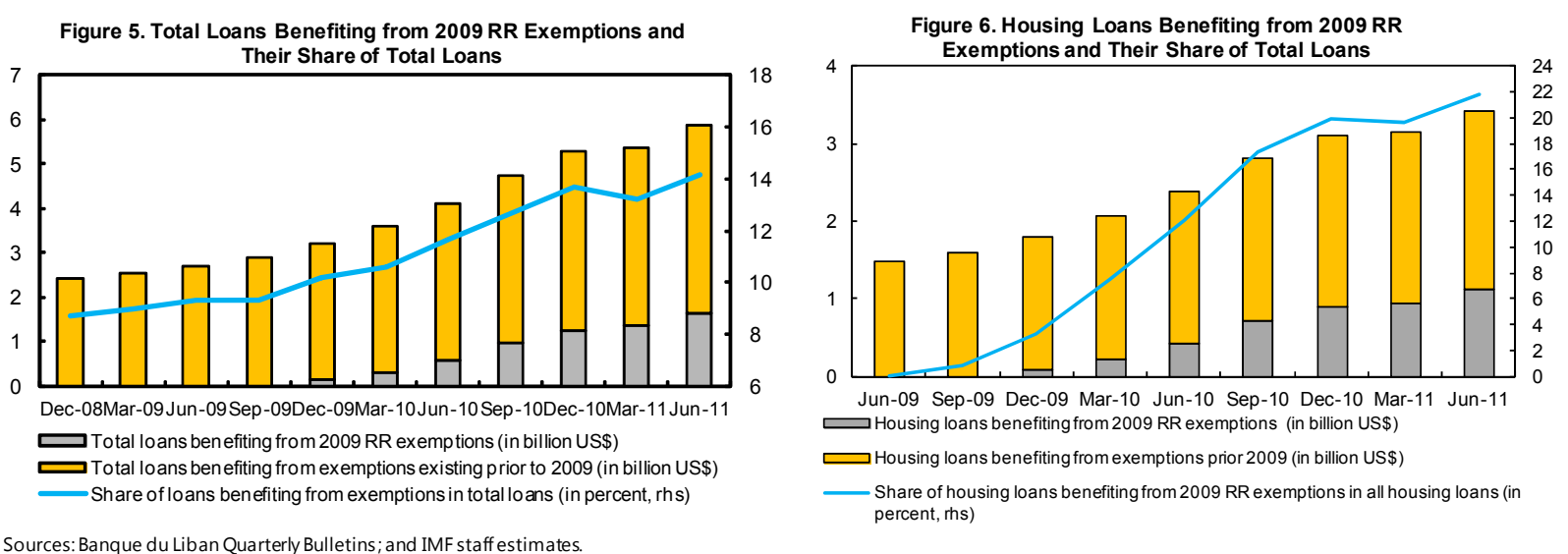

\section{B. A Disequilibrium Model of the Credit Market: Is the Credit Surge Supply or Demand Driven or Both?}

\section{This section uses a disequilibrium model to investigate if credit growth was}

supply or demand driven. ${ }^{5}$ An increase in real private sector credit can be attributed to a higher supply of credit, demand for credit, or both. The problem lies in attributing the actual observed increase in credit to movements in either supply or demand. In the disequilibrium model, this identification problem is solved by using an exclusion restriction, a variable that affects the supply or the demand for credit, but not both. Our results suggest that the credit surge was primarily supply driven, fueled by large deposit inflows and BdL schemes on LL lending.

\section{The Model}

9. The demand for credit is modeled as a function of the cost of borrowing, future economic prospects, a dummy for economic and political uncertainty, advanced country GDP and a time trend: ${ }^{6}$

$$
C_{t}^{d}=X_{1 t} \beta_{1}+u_{1 t}
$$

where $C_{t}^{d}$ is credit to the private sector deflated by the CPI index, and $X_{1 t}$ are the following explanatory variables:

\footnotetext{
${ }^{5}$ It uses the disequilibrium approach of Laffont and Garcia (1977), which was subsequently used in Ghosh and Ghosh (1999) and Poghosyan (2010).

${ }^{6}$ The role of real estate prices in increasing credit demand is likely to be an important factor, but data limitations do not allow us to pursue this.
} 
- $\quad$ The cost of borrowing is the real lending rate calculated as the weighted average of LL and FX lending rates less inflation. Two measures are used, the first calculates real lending on the basis of current inflation and the second on expected inflation (a one-year lead). The demand for credit is expected to depend negatively on the cost of borrowing.

- $\quad$ Future economic prospects are proxied by a one-month lag of the coincident indicator. ${ }^{7}$ We assume the lagged value is the market's best indicator to ascertain future prospects. As an alternative, we include a 6-month lead of the coincident indicator. Improved prospects are expected to increase demand for credit as businesses expand.

- $\quad$ Economic and political uncertainty is captured by a dummy that takes the value 1 when y-o-y changes in the seasonally adjusted coincident indicator are in the lowest $10^{\text {th }}$ percentile. Consumers' desire to borrow should decrease during episodes of uncertainty.

- An improved external environment, the level of advanced country GDP, is expected to increase credit demand reflecting greater economic opportunities for Lebanon. World industrial production is used as an alternative measure.

- A trend variable is included to capture that credit demand may increase or decrease with time.

10. The supply of credit depends on the return on credit, the return on sovereign securities, lending capacity, future economic prospects, economic and political uncertainty, and a "subsidy" index:

$$
C_{t}^{s}=X_{2 t} \beta_{2}+u_{2 t}
$$

where $C_{t}^{s}$ is defined as in the demand equation, and $X_{2 t}$ are the explanatory variables:

- $\quad$ Return on credit (real interest rate) is defined as in the demand equation. As a robustness test, the spread between loan and deposit interest rates capturing the

\footnotetext{
7 The BdL's coincident indicator is a broad measure of economic activity in Lebanon. Its components are electricity production (18.6 percent), import of petroleum products (18.2 percent), cement deliveries (16.5 percent), airport passengers (11.0 percent), trade (11.8 percent), cleared checks (12.0 percent) and money supply - M3 (12.0 percent). It is highly correlated to GDP growth at 85 percent.
} 
profitability of lending is included. A higher real interest rate and a higher spread make lending more attractive to banks, increasing the supply of credit.

- $\quad$ The return on sovereign securities (3 year T-bills) reflects alternative investment opportunities for banks. A higher return on sovereign securities should lower the supply of credit to the private sector, a typical crowding out.

- $\quad$ Lending capacity, which as part of the supply but not the demand equation helps satisfy the exclusion criterion, is defined as deposits minus required reserves deflated by inflation. A second measure of lending capacity excludes T-bills under the assumption that sovereign borrowing fully crowds out private sector lending. Higher lending capacity increases the potential supply of credit.

- $\quad$ Future economic prospects are defined as in the demand function. Banks are expected to increase credit supply with improved prospects as borrowers are more likely to remain current on their payments.

- $\quad$ Economic and political uncertainty is defined as in the demand function. Banks' willingness to lend should decrease in uncertain times.

- A subsidy index captures the supply effects of the various lending schemes. It takes a value of 4 when all lending schemes (interest subsidies, credit guarantees (Kafalat), reduced reserve requirements, and additional reduced requirements in 2009) are in place, and 0 when there are none. The index should affect LL credit supply positively.

- $\quad$ A trend variable is included, as in the demand equation.

11. If the market does not clear (for example, when interest rates do not adjust, or if there are credit subsidies or credit rationing), the demand for credit $\left(C_{t}^{d}\right)$ is not equal to the supply of credit $\left(C_{t}^{s}\right)$, but equal to the minimum of credit demanded and credit supplied. This condition is reflected in the following equation:

$$
C_{t}=\min \left(C_{t}^{d}, C_{t}^{s}\right)
$$

12. The model is solved using maximum likelihood estimation. The log-likelihood function is given by

$$
L L=\sum_{t=1}^{T} \log \left[f^{d}\left(C_{t}\right) F^{s}\left(C_{t}\right)+f^{s}\left(C_{t}\right) F^{d}\left(C_{t}\right)\right]
$$

where $f($.$) and F($.$) are the probability density and cumulative density functions, respectively.$ The estimation uses the Berndt, Hall, Hall and Hausman 1974 (BHHH) iterative procedure. 
13. We also estimate the $\mathbf{L} \mathbf{L}$ and $\mathbf{F X}$ credit markets separately. This is motivated by the high level of loans denominated in FX and the rules that restrict FX deposits from being channeled to LL lending and vice versa. While this approach allows us to capture determinants that could be specific to one market, for example the effect of subsidy schemes on LL credit, it does not allow for interaction between the markets, i.e., a decrease in interest rates in one market could draw participants from the other.

\section{The Estimation}

14. The coefficient estimates for the demand and supply equations using monthly data from the period $1997 \mathrm{M1}$ to $2011 \mathrm{M6}$ are in Table $2 .^{8}$

- The main determinants of credit demand are local and global economic prospects. A better external environment increases credit demand whether proxied by advanced country GDP or the world production index. ${ }^{9}$ As expected, brighter economic prospects (current and future) increase credit demand with an elasticity of 0.4 . The return on borrowing has no effect on credit demand. A similar result is obtained defining the real cost of borrowing using expected inflation. Uncertainty and the time trend are also insignificant.

- Credit supply is affected by lending capacity, returns and future economic prospects. Lending capacity is positive and significant, with an elasticity of 1.3 (for a one percent increase in lending capacity, credit increases by 1.3 percent), suggesting that the availability of lendable funds is important in determining the supply of credit. The result is robust to excluding sovereign borrowing from lendable funds, although the coefficient is smaller. A higher return on credit increases credit supply and the coefficient on the real interest rate is positive and significant (with an elasticity of 0.2 ); the result is robust to using the spread. Good economic prospects also increase credit supply. Surprisingly, while uncertainty decreases banks' desire to lend, it does not seem to be an important factor as the coefficient is statistically insignificant. This indicates that, while banks reduce their supply of credit during times of uncertainty, the more important factor is the availability of funds. Other investment opportunities given by the return on sovereign T-bills (both U.S. and Lebanese) is insignificant. Subsidized lending in LL captured by the subsidy index does not have a significant impact on overall credit supply.

\footnotetext{
${ }^{8}$ Because there is a cointegrating relationship between credit demanded and the actual level of credit, and credit supplied and the actual level of credit, estimation is in levels.
}

${ }^{9}$ See Kyobe and Sadikov (2012). 
Table 2. Maximum Likelihood Estimation of Disequilibrium Model

\begin{tabular}{lll}
\hline & Coefficient & Std. Error \\
\hline Credit Demand & $4.59^{* * *}$ & \\
\hline constant & 0.04 & 0.14 \\
real interest rate & $0.43^{* * *}$ & 0.14 \\
log (coincident_sa) & 0.00 & 0.18 \\
uncertainty (dummy) & $0.59^{* * *}$ & 0.08 \\
log(adv. country gdp) & 0.03 & 0.03 \\
time trend & & \\
\hline Credit Supply & $-6.13^{* * *}$ & 0.13 \\
\hline constant & $0.14{ }^{* * *}$ & 0.02 \\
real interest rate & 0.00 & 0.01 \\
T-bill & $1.29^{* * *}$ & 0.04 \\
log(lending capacity) & $0.29{ }^{* * *}$ & 0.09 \\
log (coincident_sa) & -0.01 & 0.02 \\
uncertainty (dummy) & -0.06 & 0.13 \\
subsidy index & $-0.03^{* *}$ & 0.01 \\
time trend & 174 & \\
\hline Number of observations & 278.11 & \\
Log likelihood & 1.60 & \\
Avg. log likelihood & -3.04 & \\
Akaike info criterion & -2.78 & \\
Schwarz criterion & & \\
\hline Sources: Lebanese authorities; and IMF staff estimates. & \\
*** significant at the 99 \% level, ** 95\% level & & \\
Estimations use the BHHH iterative procedure. & \\
\hline
\end{tabular}

\section{Estimating the $\mathbf{L L}$ and $\mathbf{F X}$ markets separately yield similar results (Tables A1} and A2 in the Appendix). In the LL market, all coefficients in the credit demand equation are of the correct sign, though only good economic prospects significantly explain an increase in LL credit demand. In the supply equation, the subsidy index is positive and significant, supporting the hypothesis that subsidy schemes were effective in increasing LL credit supply. The coefficients on lending capacity, future economic prospects and alternative investment opportunities are of the correct sign, but insignificant. Weak results could be explained by the relatively small share of LL lending in private sector credit. FX market estimation results are stronger. In particular, improvements in alternative investment opportunities decrease credit supply. Remaining results are similar to the joint specification.

\section{The estimated credit demand and supply are compared to the actual level of} credit (Figure 7). Results indicate that excess credit demand at the beginning of the sample period was met by supply in 2000 , coinciding with the introduction of the Kafalat credit 
guarantee schemes. But by 2005 and for the next four years, credit demand, possibly fueled by demand for real estate again outpaced supply. Lending capacity increases in mid-2009 with large deposit inflows to Lebanon and the reduction of the reserve requirements, and, as a result, credit supply matches demand. Credit growth slows down in 2011, coinciding with a period of uncertainty with the dissolution of government. Starting in August 2010, actual levels of credit are higher than credit demand and credit supply predicted by the model. This is potentially explained by a reduced bank appetite for government paper due to increased political tensions since mid-2010, which has meant more funding directed to private sector lending.
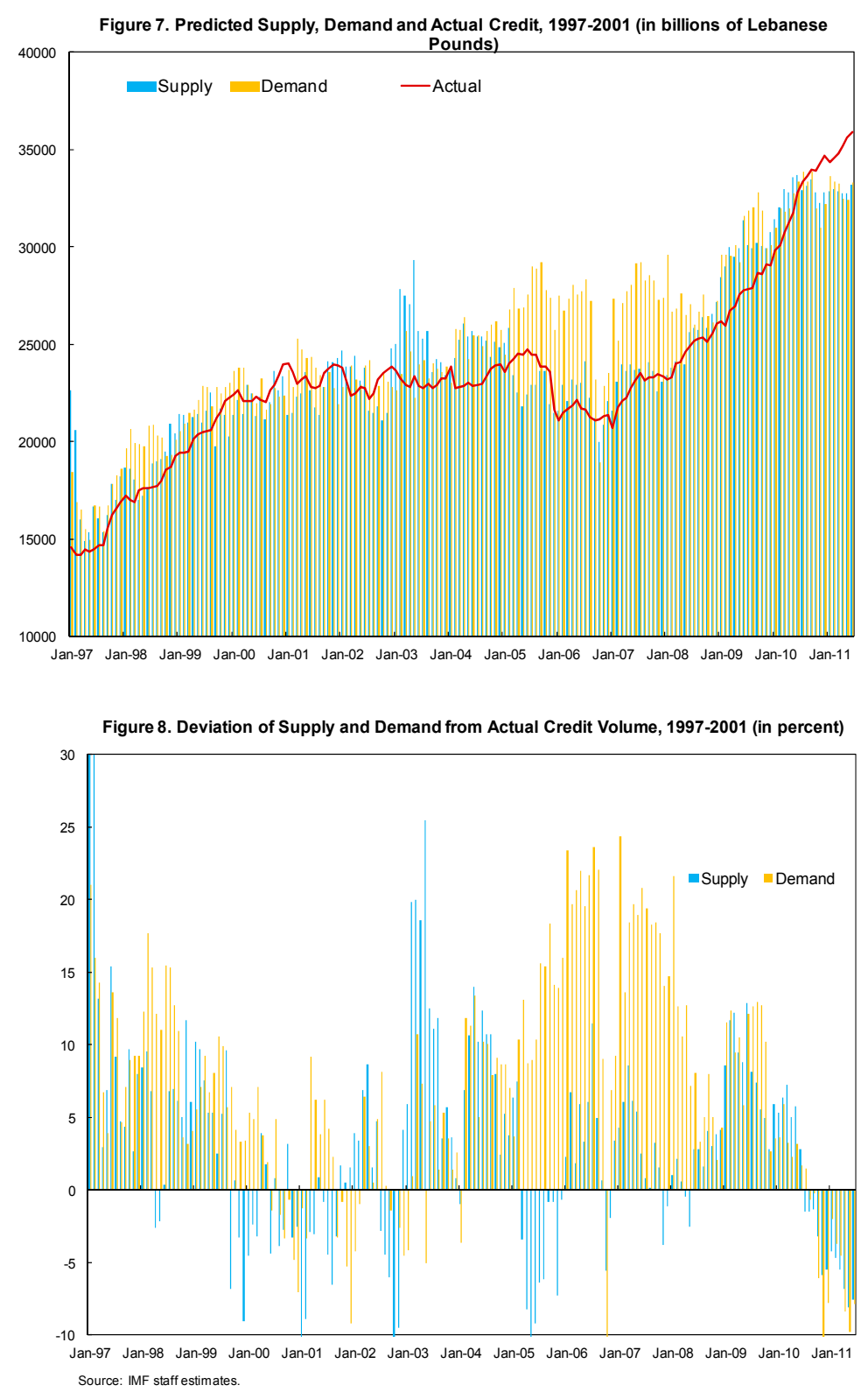


\section{Conclusion}

17. Estimation of the credit market shows that credit supply appears to play a more dominant role than credit demand.

18. BdL schemes were effective in bringing down LL lending rates and encouraging LL credit growth. Schemes did not have a significant impact on total credit as lending was substituted away from FX to LL credit, following a de-dollarization of the deposit base which resulted in ample LL liquidity. The scheme facilitated substitution from FX to LL lending, helping a quicker adjustment on the asset side. While strong credit growth in 2010 raised risks of overheating, this is less of a concern now that it has decelerated. 


\section{Appendix}

Table A1. LL Market Specification

\begin{tabular}{lcccc}
\hline & Coefficient & Std. Error & z-Statistic & Prob. \\
\hline Credit Demand & & & & \\
\hline constant & 1.87 & 12.12 & 0.15 & 0.88 \\
real interest rate & 0.01 & 0.03 & 0.39 & 0.69 \\
log (coincident_sa) & $1.11^{* *}$ & 0.48 & 2.30 & 0.02 \\
uncertainty & 0.02 & 0.29 & 0.06 & 0.95 \\
log(adv. country gdp) & 0.17 & 2.21 & 0.08 & 0.94 \\
\hline Credit Supply & & & & \\
\hline constant & $6.68^{* * *}$ & 2.26 & 2.96 & 0.00 \\
real interest rate & 0.00 & 0.04 & -0.09 & 0.93 \\
T-bill & -0.03 & 0.03 & -1.21 & 0.23 \\
log(lending capacity) & 0.15 & 0.19 & 0.78 & 0.43 \\
log (coincident_sa) & -0.04 & 0.35 & -0.12 & 0.90 \\
uncertainty & 0.03 & 0.09 & 0.30 & 0.77 \\
subsidy index & $0.21 * *$ & 0.08 & 2.55 & 0.01 \\
\hline Number of observations & 112 & & & \\
Log likelihood & 97.48 & & & \\
Avg. log likelihood & 0.87 & & & \\
Akaike info criterion & -1.53 & & & \\
Schwarz criterion & -1.24 & & & \\
\hline Source: IIF staff & & & & \\
\hline
\end{tabular}

Source: IMF staff estimates.

*** significant at the $99 \%$ level, ${ }^{* *} 95 \%$ level

Estimations use the $\mathrm{BHHH}$ iterative procedure.

Table A2. FX Market Specification

\begin{tabular}{lcccc}
\hline Credit Demand & Coefficient & Std. Error & Z-Statistic & Prob. \\
\hline constant & 8.40 & 0.52 & 16.28 & 0.00 \\
real interest rate & 0.01 & 0.03 & 0.31 & 0.76 \\
log (coincident_sa) & $0.76^{* *}$ & 0.12 & 6.34 & 0.00 \\
uncertainty & -0.03 & 0.19 & -0.14 & 0.89 \\
log(adv. country gdp) & $-0.65^{* *}$ & 0.04 & -17.45 & 0.00 \\
\hline Credit Supply & & & & \\
\hline constant & 1.77 & 1.43 & 1.24 & 0.21 \\
real interest rate & $0.09 * *$ & 0.02 & 5.40 & 0.00 \\
Tbill & $-0.05 * *$ & 0.01 & -8.27 & 0.00 \\
log(lending capacity) & $0.64^{* *}$ & 0.15 & 4.30 & 0.00 \\
log (coincident_sa) & -0.02 & 0.06 & -0.26 & 0.79 \\
uncertainty & 0.00 & 0.02 & 0.22 & 0.82 \\
time trend & 0.02 ** & 0.01 & 2.21 & 0.03 \\
\hline Number of observations & 112 & & & \\
Log likelihood & 209.15 & & & \\
Avg. log likelihood & 1.87 & & & \\
Akaike info criterion & -3.52 & & & \\
Schwarz criterion & -3.23 & & & \\
\hline Source: IMF staff estimates. & & & & \\
$* * *$ significant at the $99 \%$ level, ** $95 \%$ level & & & \\
Estimations use the BHHH iterative procedure. & & & \\
\hline
\end{tabular}

\section{CInternational Monetary Fund. Not for Redistribution}




\section{References}

Berndt, E., B. Hall, R. Hall and J. Hausman, (1974) "Estimation and Inference in Nonlinear Structural Models," Annals of Social Measurement, 3: 653-65.

Ghosh, A. and S. Ghosh, (1999) "East Asia in the Aftermath: Was There a Crunch?," IMF Working Paper WP/99/38.

Kyobe, A. and A. Sadikov, (2012) "The Price of Oil and Lebanese Economy: A Blessing in Disguise," Lebanon-Selected Issues, Chapter 2.

Laffont, J. and R. Garcia, (1977) "Disequilibrium Econometrics for Business Loans," Econometrica, 45(5): 1187-1204.

Maddala, G.S., (1989) "Limited Dependent and Qualitative Variables in Econometrics," Cambridge: Cambridge University Press.

Poghosyan, T., (2010) "Slowdown of Credit Flows in Jordan in the Wake of the Global Financial Crisis: Supply or Demand Driven?," IMF Working Paper. 


\section{The Price Of OIL AND The Lebanese Economy: A Blessing in Disguise? ${ }^{1}$}

Conventional wisdom is that higher oil prices hurt oil importers. In Lebanon, however, close links with major oil exporters in the region suggest that higher oil prices could benefit the economy through higher capital inflows and external demand. A VAR (Vector Autoregression) analysis confirms that higher oil prices increase Lebanese exports, tourism receipts, deposit inflows, and private sector credit and that oil price changes are a considerable source of volatility in these indicators. A VEC (Vector Error-Correction) estimation shows that the oil price is a main long-run driver of growth in Lebanon.

1. Higher oil prices typically hurt oil importers. First, a rise in oil prices depresses economic activity as increased oil spending crowds out non-oil consumption and investment. Second, it leads to a worsening of terms of trade and a rise in imports, causing the current account to deteriorate.

\section{In Lebanon, however, higher oil prices have an overall positive impact on} activity. $^{2}$ Given its close economic ties with major oil exporters in the region, Lebanon benefits from an increase in external demand and capital inflows as oil exporters recycle their revenue windfall. One could then observe that an oil price shock leads not only to higher imports, but also to a rise in externally-driven activities such as exports, tourism, and FDI and deposit inflows. Moreover, with many Lebanese working in oil exporting countries, remittances could go up too.

\section{This note investigates the impact of an oil price shock on key indicators of} output in Lebanon. First, the main channels through which an oil price shock can affect Lebanon's economy are discussed. Second, using VAR and VEC models the direction, pace, and strength of transmission of the shock to high-frequency economic indicators are estimated.

\section{A. Transmission Channels}

\section{The coincident indicator is a measure of aggregate economic activity in}

Lebanon. The indicator is a weighted index comprising monthly indicators from key sectors. It is highly correlated to GDP growth at 85 percent. Economic activity (i.e., the coincident indicator and its components) will be affected by an oil price shock through various transmission channels, specifically:

\footnotetext{
${ }^{1}$ Annette Kyobe and Azim Sadikov.

${ }^{2}$ Mohaddes and Raissi (2011) find that the oil price is one of the main long-run drivers of output in Jordan.
} 


\section{First Round Effects}

- Imports. Higher oil imports represent an income transfer from Lebanon to oil exporters. Oil imports accounted for about 20 percent of Lebanon's goods imports during 2009-10 or almost 10 percent of GDP. Everything else unchanged, an increase in the price of oil by $\$ 10$ per barrel would increase nominal imports by about $\$ 500$ million or 1.3 percent of 2010 GDP. Real oil imports however could fall, particularly over time, as the economy adjusts to higher oil prices by consuming less oil, though this mechanism is somewhat impeded because of subsidies to the electricity company and reductions in excises in response to higher oil prices (see next bullet). Real non-oil imports could fall too, at least in the near term, reflecting reduced real income.

- $\quad$ Fiscal balances. Lebanon provides a subsidy to the electricity company to keep tariffs constant (on average 4 percent of GDP per year during 2006-10) and imposes excises on fuel imports (about 2 percent of GDP per year during 2009-10). ${ }^{3,4}$ These two policies partially offset each other with the net effect being a worsening of 0.5 percent of GDP in the fiscal balance for every $\$ 10$ per barrel increase in the oil price. From an aggregate demand perspective and in the absence of discretionary adjustment, this policy works like a shock absorber, helping cushion the domestic economy from the full impact of the oil price increase.

\section{Second Round Effects}

- $\quad$ Exports. Oil exporters account for about one third of Lebanon' goods exports and tourism receipts. Assuming that the income elasticity of external demand in oil exporters equals one, a 1 percent increase in oil-exporters' income would generate an estimated $\$ 44$ million ( 1 percent of GDP) increase in good exports and tourism revenue in Lebanon.

- Capital inflows. For an oil importer facing increased balance of payments needs due to an oil price shock, an increase in capital inflows would provide financing, easing immediate balance of payments pressures and reducing the pace and the size of external adjustment. Capital inflows can also stimulate domestic activity through an expansion of credit. While no data are available, anecdotal evidence suggests that large FDI and deposit inflows to Lebanon originate from oil exporters. Indeed, the correlation between the one-year lagged sum of the current account surpluses of the

\footnotetext{
${ }^{3}$ The subsidy is inefficient, poorly targeted, and costly (El-Ganainy and Nakhle (2012)).

${ }^{4}$ Fuel excises were reduced by about half in February 2011 (equivalent to an annual revenue loss of around 1 percent).
} 
MENA region oil exporters and current year FDI inflows to Lebanon is 62 percent; and between the surpluses and current year deposit inflows to Lebanon 65 percent.

- Remittances. Lebanon is one of the world's largest recipients of remittances as a share of GDP, much of which comes from the Gulf Cooperation Council (GCC). Remittance inflows reached $\$ 6.7$ billion in 2010 or 17 percent of GDP, of which at least 60 percent was from oil exporters. Assuming unit elasticity of remittances to oil exporters' income implies that a 1 percent increase in their income would generate an estimated \$40 million (1 percent of GDP) increase in remittances in Lebanon.

\section{B. Impulse Response Functions}

5. We estimate three-variable reduced form VARs. ${ }^{5}$ Each model includes one domestic variable, the real oil price, and the average of US and EU production indices as a proxy for world output. ${ }^{6}$ Domestic variables include the coincident indicator, goods imports, goods exports, passenger arrivals, bank deposits, and private sector credit. The coincident indicator proxies overall economic activity, while the other domestic variables capture the transmission channels described above. We do not include more than one domestic variable into each VAR because each reflects a distinctly separate transmission channel from the oil price to the economy. The proxy for world output accounts for the fact that all oil price shocks since the early 1990s were demand driven.

\section{Impulse response analyses using the Cholesky decomposition show an overall} positive impact of an oil price shock on economic activity. This is explained by strong second-round effects (Figure 1).

- Coincident indicator. The impulse response functions of the coincident indicator show a positive impact of higher oil prices. The impact comes with a lag, with the coincident indicator not responding in a statistically significant way to an oil price shock until the fourth quarter. By the end of the second year, though, a one percent increase in the real oil price would cause a 0.13 percent increase in the indicator, further increasing to 0.17 percent by the end of the third year. This translates into real GDP being 0.8-1.2 percent higher two to three years after a 10 percent increase in the real price of oil. A positive response of the coincident indicator to an oil price increase is a surprising finding. For an oil-importing country like Lebanon, this result can only be explained by the presence of large positive second-round effects operating through various transmission channels.

\footnotetext{
${ }^{5}$ See the appendix with technical notes for more detail on the estimation strategy.

${ }^{6}$ This proxy correlates highly with the production indices for Japan and emerging countries $(0.80)$.
} 
- Imports. In contrast to the coincident indicator, imports of goods respond to an oil price shock immediately. Real imports fall by 0.43 percent in the second quarter following a one percent increase in the oil price. This negative impact starts to wane, disappearing completely by the sixth quarter, reflecting a gradual adjustment of the economy. Over time, the impact becomes positive though not statistically significant.

- $\quad$ Exports. An increase in the oil price leads to a rise in goods exports, with the strongest effect three quarters after the shock. A one percent increase in oil prices results in an average increase of 0.26 percent in exports during the next four quarters. The impact however lasts only for five quarters.

- $\quad$ Passenger arrivals. Passenger arrivals respond to an oil price shock with a lag, with the impact turning statistically significant in the fourth quarter. A one percent hike in the oil price leads to a 0.21 percent rise in passenger arrivals. Consistent with the impact on goods exports, the positive effect wears off by the tenth quarter.

- $\quad$ Bank deposits. Quarterly data on remittances and foreign direct investment (as a proxy for capital inflows) are generally not reliable and come with extended lags. We therefore proxy them with bank deposits. ${ }^{7}$ Deposit inflows would rise by the fourth quarter becoming significant in the eighth quarter, in response to an increase in the oil price; they would be on average 0.20 percent higher in the third to fifth years after a one percent positive shock in oil price.

- Private sector credit. Not surprisingly, private sector credit responds to an oil price shock in a pattern similar to that of bank deposits. ${ }^{8} \mathrm{~A}$ one percent rise in the oil price leads to a 0.21 percent increase in private sector credit in the third year.

\section{The variance decomposition analysis shows that the oil price shock is a} considerable source of volatility for all variables (Table 1). An oil price shock accounts anywhere from 20 percent up to 50 percent of the variation in the variables measuring different aspects of economic activity in Lebanon. For the coincident indicator, imports, and bank deposits, the oil price is the largest and most persistent source of volatility, accounting for 59, 42 and 52 percent of their variation, respectively, even in the fifth year. The explanatory power of the oil price shock in the variation of exports, passenger arrivals, and private sector credit is somewhat smaller, but still considerable.

\footnotetext{
${ }^{7}$ We use the sum of resident and nonresident deposits because it is difficult to determine residency for the large number of bank accounts owned by nonresident Lebanese passport holders.

${ }^{8}$ Kyobe, Nakhle, and Sadikov (2012).
} 


\section{Long-Run Relationship in a VEC Model}

8. A Vector Error-Correction (VEC) estimates the long-run relation between the oil price and economic activity in Lebanon through the capital inflows channel. Since there is no macroeconomic model that could guide the construction of a Lebanon-specific VEC equation, we rely on our understanding of the transmission of an oil price shock through the economy in modeling a long-run relationship and on a data-driven approach in specifying its short-run dynamics. In contrast to transmission channels operating through exports or imports, which are part of the national accounts equation, the capital inflows channel works in a sequence of successive steps, affecting first domestic liquidity, then domestic interest rates and private sector lending, and finally output.

9. The oil price is one of the main long-run drivers of Lebanon's economy (Table

2). The VEC model confirms the existence of a long-run relationship between the oil price, bank deposits, loan interest rates, and economic activity. It shows that an oil price shock operates through second-round transmission channels. In the long term, a rise in the oil price leads to an increase in bank deposits, with the resulting high domestic liquidity prompting banks to reduce lending rates, which in turn stimulates the economy.

\section{Conclusion}

\section{We find that an adverse oil price shock has a positive overall impact on} economic activity in Lebanon. This is a counterintuitive finding for an oil importing country, but can be explained by strong positive second-round effects offsetting the negative first-round impact of an oil price shock. These second-round effects operate through various trade and financial linkages between Lebanon and large oil exporters in the region such as goods exports, tourism receipts, and deposit inflows. The oil price is a considerable source of volatility for most activity indicators in Lebanon and one of the main long-run drivers of the economy.

\section{Strengthening trade and financial linkages with the region's oil exporters would} help in hedging against oil price shocks. Greater integration with the region would allow Lebanon to further benefit from increased income of oil exporters during oil price booms, strengthening the resilience of the economy. It would also reduce the need to support aggregate demand through fiscal support measures because consumption and investment could be sustained through greater trade and capital flows. 
Figure 1 (cont'd). Orthogonalized Impulse-Response Functions to a Positive One-Standard Deviation Oil Price Innovation (Cholesky Ordering)
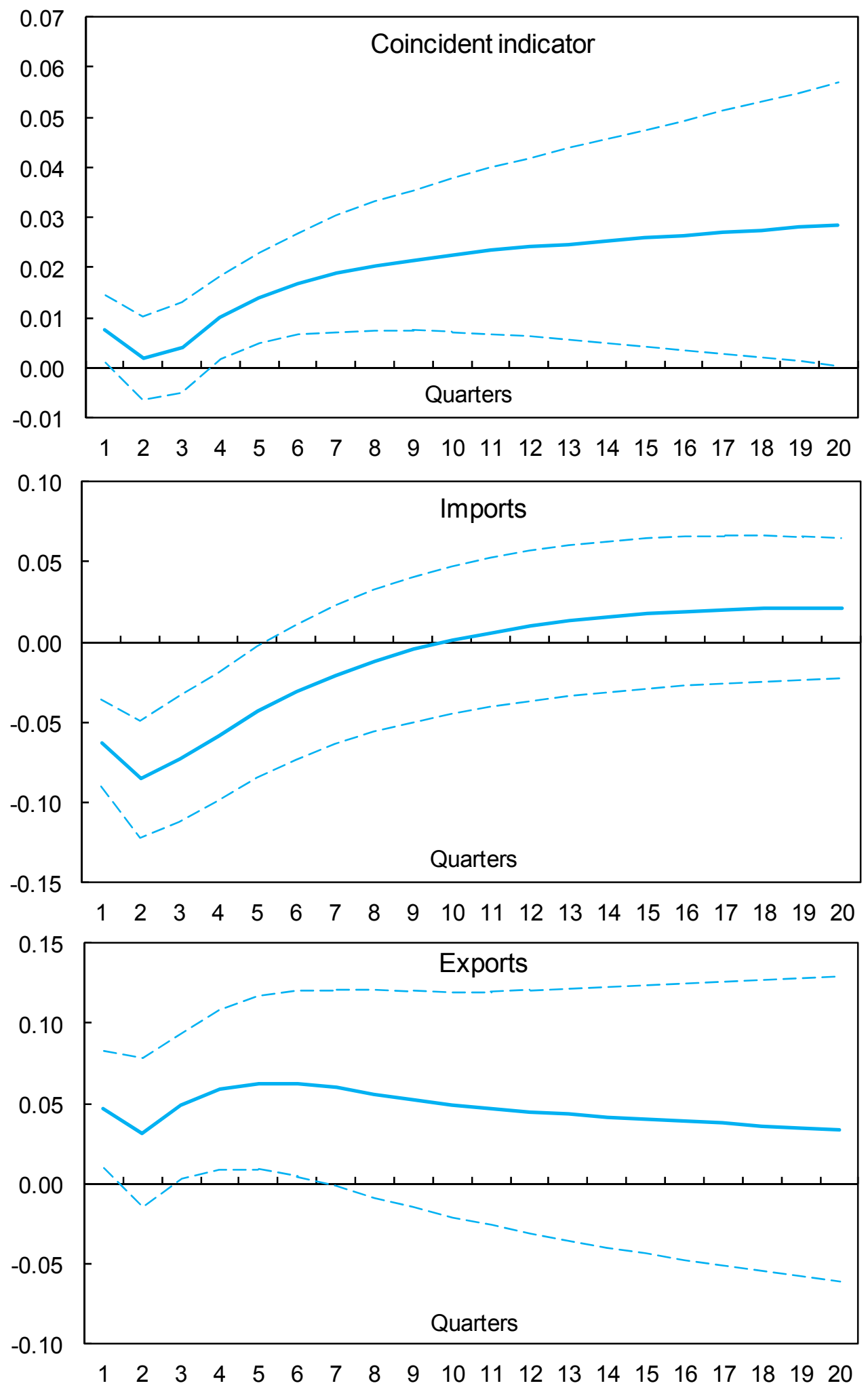

(CInternational Monetary Fund. Not for Redistribution 
Figure 1 (concluded). Orthogonalized Impulse-Response Functions to a Positive One-Standard Deviation Oil Price Innovation (Cholesky Ordering)
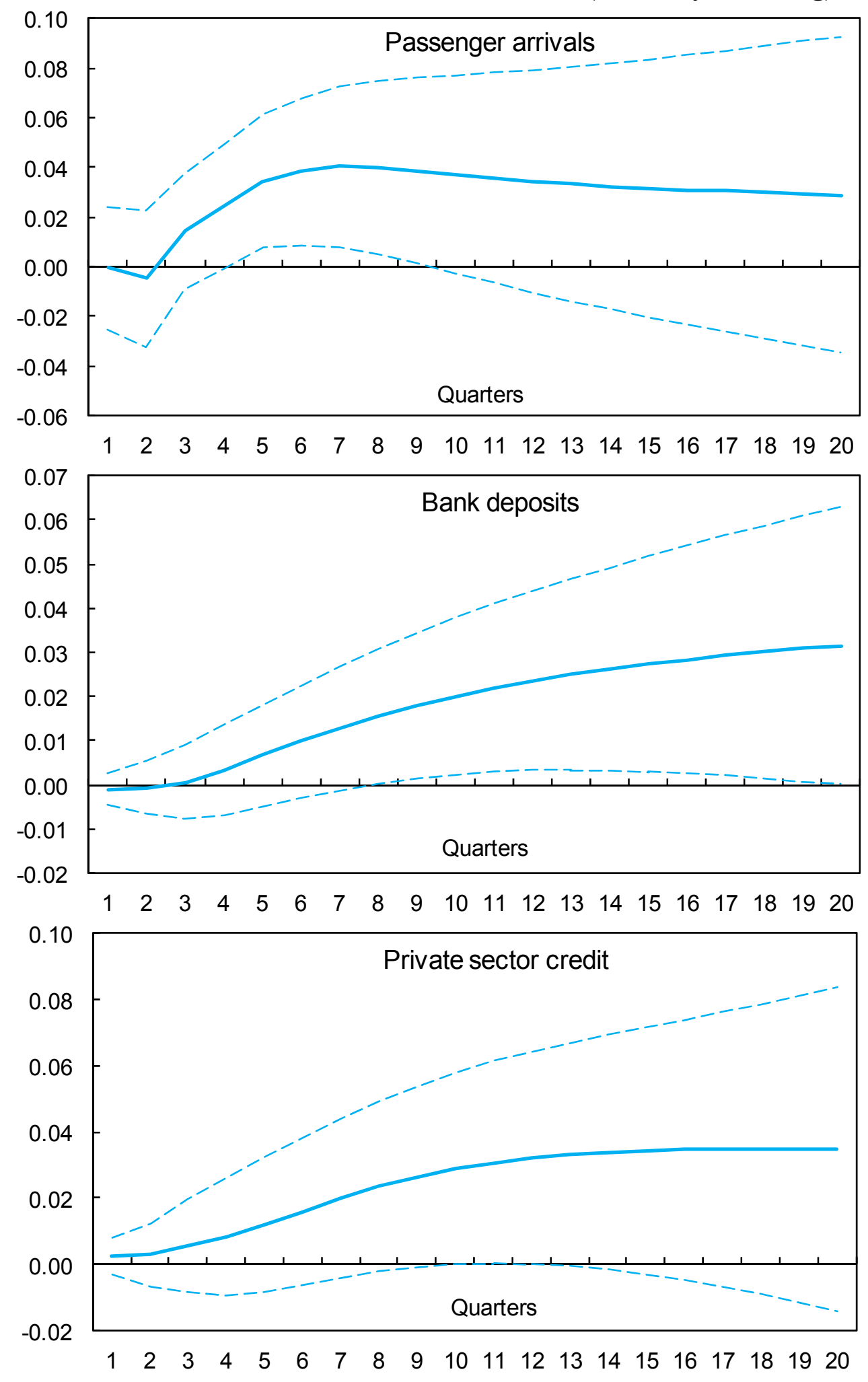

(CInternational Monetary Fund. Not for Redistribution 
Table 1. Variance Decomposition (percent share of variance explained by an oil price shock)

\begin{tabular}{rrrrrrr}
\hline Quarters & $\begin{array}{r}\text { Coincident } \\
\text { indicator }\end{array}$ & Real imports & Real exports & $\begin{array}{r}\text { Passenger } \\
\text { arrivals }\end{array}$ & $\begin{array}{r}\text { Real bank } \\
\text { deposits }\end{array}$ & $\begin{array}{r}\text { Real private } \\
\text { sector credit }\end{array}$ \\
\hline 1 & 7.0 & 0.0 & 8.8 & 0.0 & 0.4 & 1.3 \\
2 & 6.1 & 2.6 & 8.6 & 0.2 & 0.2 & 1.2 \\
3 & 6.3 & 2.7 & 11.1 & 1.4 & 0.1 & 1.9 \\
4 & 11.2 & 5.7 & 14.1 & 4.2 & 0.8 & 2.8 \\
5 & 18.8 & 10.6 & 16.5 & 8.3 & 2.3 & 4.4 \\
6 & 26.3 & 15.2 & 18.0 & 12.1 & 4.8 & 6.4 \\
7 & 32.6 & 19.5 & 18.8 & 15.0 & 8.0 & 8.9 \\
8 & 37.8 & 23.3 & 19.1 & 17.1 & 11.6 & 11.6 \\
9 & 41.9 & 26.8 & 19.1 & 18.4 & 15.6 & 14.4 \\
10 & 45.3 & 29.8 & 18.9 & 19.3 & 19.7 & 16.9 \\
11 & 48.0 & 32.4 & 18.7 & 19.8 & 23.8 & 19.3 \\
12 & 50.2 & 34.5 & 18.4 & 20.1 & 27.8 & 21.4 \\
13 & 52.0 & 36.3 & 18.2 & 20.2 & 31.6 & 23.2 \\
14 & 53.5 & 37.8 & 17.9 & 20.3 & 35.2 & 24.7 \\
15 & 54.8 & 39.0 & 17.6 & 20.3 & 38.5 & 26.0 \\
16 & 55.9 & 39.9 & 17.4 & 20.3 & 41.6 & 27.1 \\
17 & 56.9 & 40.7 & 17.1 & 20.3 & 44.5 & 27.9 \\
18 & 57.7 & 41.3 & 16.9 & 20.2 & 47.2 & 28.6 \\
19 & 58.4 & 41.8 & 16.6 & 20.1 & 49.6 & 29.1 \\
20 & 59.1 & 42.1 & 16.4 & 20.0 & 51.9 & 29.6 \\
\hline
\end{tabular}


Table 2. Vector Error-Correction Model

Cointegrating equation:

error_correct $_{t}=\mathrm{Cl}_{t}+0.01 r_{t}-0.41 \mathrm{dep}_{t}-0.13 p$-oil $t_{t}+1.34 w_{t}-9.27$

$$
\begin{array}{lll}
(0.00) & (0.03) \quad(0.03) \quad(0.17)
\end{array}
$$

Error-correction equations:

\begin{tabular}{|c|c|c|c|c|c|}
\hline Equation & $\Delta w_{t}$ & $\Delta p$-oil ${ }_{t}$ & $\Delta d e p_{t}$ & $\Delta r_{t}$ & $\Delta C l_{t}$ \\
\hline \multirow[t]{2}{*}{ error_correct $t_{t-1}$} & -0.02 & -1.06 & 0.08 & 10.14 & 0.34 \\
\hline & $(0.03)$ & $(0.44)$ & $(0.05)$ & $(5.90)$ & $(0.10)$ \\
\hline \multirow[t]{2}{*}{$\Delta w_{t-1}$} & 0.75 & 1.79 & $(0.20)$ & 2.71 & $(0.05)$ \\
\hline & $(0.14)$ & (1.97) & $(0.24)$ & $(26.43)$ & $(0.43)$ \\
\hline \multirow[t]{2}{*}{$\Delta w_{t-2}$} & $(0.12)$ & $(1.33)$ & 0.16 & $(23.87)$ & 0.08 \\
\hline & $(0.12)$ & (1.71) & $(0.21)$ & $(23.05)$ & $(0.38)$ \\
\hline \multirow[t]{2}{*}{$\Delta p$-oil $t_{t-1}$} & 0.03 & 0.26 & $(0.00)$ & $(5.76)$ & $(0.03)$ \\
\hline & $(0.01)$ & $(0.15)$ & $(0.02)$ & $(2.00)$ & $(0.03)$ \\
\hline \multirow[t]{2}{*}{$\Delta p$-oil ${ }_{t-2}$} & $(0.03)$ & $(0.23)$ & 0.00 & 2.00 & $(0.03)$ \\
\hline & $(0.01)$ & $(0.15)$ & $(0.02)$ & (2.07) & $(0.03)$ \\
\hline \multirow[t]{2}{*}{$\Delta d e p_{t-1}$} & 0.12 & 0.34 & 0.36 & $(43.91)$ & $(0.13)$ \\
\hline & $(0.08)$ & (1.09) & $(0.13)$ & (14.69) & $(0.24)$ \\
\hline \multirow[t]{2}{*}{$\Delta d e p_{t-2}$} & 0.00 & $(0.32)$ & 0.34 & 32.31 & $(0.08)$ \\
\hline & $(0.08)$ & $(1.14)$ & $(0.14)$ & $(15.38)$ & $(0.25)$ \\
\hline \multirow[t]{2}{*}{$\Delta r_{t-1}$} & $(0.00)$ & 0.00 & $(0.00)$ & 0.48 & $(0.00)$ \\
\hline & $(0.00)$ & $(0.01)$ & $(0.00)$ & $(0.07)$ & $(0.00)$ \\
\hline \multirow[t]{2}{*}{$\Delta r_{t-2}$} & 0.00 & $(0.00)$ & 0.00 & $(0.26)$ & 0.00 \\
\hline & $(0.00)$ & $(0.00)$ & $(0.00)$ & $(0.05)$ & $(0.00)$ \\
\hline \multirow[t]{2}{*}{$\Delta C l_{t-1}$} & $(0.04)$ & $(0.65)$ & 0.03 & 4.96 & $(0.25)$ \\
\hline & $(0.04)$ & $(0.50)$ & $(0.06)$ & $(6.72)$ & $(0.11)$ \\
\hline \multirow[t]{2}{*}{$\Delta C l_{t-2}$} & $(0.04)$ & $(0.23)$ & $(0.01)$ & $(0.16)$ & $(0.09)$ \\
\hline & $(0.03)$ & $(0.41)$ & $(0.05)$ & $(5.54)$ & $(0.09)$ \\
\hline \multirow[t]{2}{*}{ intercept } & $(0.00)$ & 0.03 & 0.01 & 0.28 & 0.03 \\
\hline & $(0.00)$ & $(0.03)$ & $(0.00)$ & $(0.42)$ & $(0.01)$ \\
\hline \multirow[t]{2}{*}{ dummy $_{2006}$ war } & 0.00 & $(0.05)$ & $(0.07)$ & $(2.86)$ & $(0.29)$ \\
\hline & $(0.01)$ & $(0.14)$ & $(0.02)$ & (1.91) & $(0.03)$ \\
\hline \multirow[t]{2}{*}{$d_{u m m y} 1 s t-q$} & 0.01 & 0.06 & $(0.04)$ & $(0.18)$ & $(0.00)$ \\
\hline & $(0.00)$ & $(0.05)$ & $(0.01)$ & $(0.71)$ & $(0.01)$ \\
\hline \multirow[t]{2}{*}{$d_{u m m y} 2 n d-q$} & 0.01 & 0.10 & $(0.02)$ & $(1.29)$ & $(0.01)$ \\
\hline & $(0.00)$ & $(0.07)$ & $(0.01)$ & $(0.92)$ & $(0.01)$ \\
\hline \multirow[t]{2}{*}{$d^{\prime} u m m y_{3 r d-q}$} & 0.01 & 0.05 & $(0.00)$ & 0.71 & $(0.02)$ \\
\hline & $(0.00)$ & $(0.05)$ & $(0.01)$ & $(0.70)$ & $(0.01)$ \\
\hline
\end{tabular}

Notes: $w_{t}$ is a proxy for the global output, measured as an average of the U.S. and EU production indices; $p$-oil is the real price of oil; dep $_{t}$ is the stock of commercial bank deposits; $r_{t}$ is the real loan interest rate; $\mathrm{C}_{t}$ is the coincident indicator of economic activity. Standard errors are reported in brackets. 


\section{Appendix}

A standard VAR model with a parsimonious lag structure is used. The VAR includes dummies to control for seasonality and the impact of the war with Israel. ${ }^{9}$ We use the Likelihood Ratio test and Akaike and Schwarz criteria to choose the optimal lag structure for each AR specification. In case of a conflict among tests, we follow the Akaike criterion.

Data are quarterly from Q1 1993 through Q1 2011. Nominal variables are converted to constant U.S. dollar terms using U.S. CPI. For real imports, an average of the U.S. CPI and U.S. dollar oil price is used, weighted by shares of non-oil and oil imports. Monthly observations of these variables come from the website of the Banque du Liban. The real oil price and average production indices for the EU and the U.S. are available from Eurostat and IMF International Financial Statistics, respectively. All variables, except for interest rates, are in logarithms and are integrated of order one. The three variables in each VAR equation are cointegrated, so they can be estimated in levels. The residuals from each VAR equation are stationary.

Producing orthogonalized impulse-response functions using the Cholesky decomposition requires choosing an ordering of variables, which attributes all effects in any common component to the variable that comes first. Hence, a shock to the first variable in the system affects all other variables contemporaneously, but shocks to other variables have no contemporaneous impact on the first variable; the second variable affects contemporaneously the other variables (but not the first), and is not contemporaneously affected by them and so forth. We have chosen the following ordering: world output, real oil price and domestic activity. The proxy for world output is treated as weakly exogenous because every oil price shock during our sample period has been demand driven; it is therefore the first variable in the model. The oil price is exogenous to Lebanon, which is why we select the real oil price as the second variable. The domestic activity variable thus comes third.

\footnotetext{
${ }^{9}$ While Lebanon has been hit by many domestic political or regional shocks, the war with Israel appears to have had the most profound impact on the economy.
} 


\section{References}

Jiménez-Rodriguez R. and Sanchez M., (2004) "Oil Price Shocks and Real GDP Growth, Empirical Evidence for some OECD Countries," European Central Bank Working Paper.

El-Ganainy, A. and Nakhle N., (2012) "Poverty, Social Safety Net and Subsidies in Lebanon," Lebanon-Selected Issues, Chapter 4.

Kapoor, A., (2011) “The Economic Impact of Oil Price Shocks on Emerging Markets," Claremont McKenna College, Senior Theses, Paper 139.

Kumar S., (2009) "The Macroeconomic Effects of Oil Price Shocks: Empirical Evidence for India," Economics Bulletin, Vol. 29 no.1.

Kyobe, A. Nakhle, N. and Sadikov, A., (2012) "Private Sector Credit Growth in LebanonSupply or Demand Driven?," Lebanon-Selected Issues, Chapter 1.

Mohaddes K. and Raissi M., (2011) “Oil Prices, External Income and Growth: Lessons from Jordan," IMF Working Paper. 


\section{CONSTRAINTS TO GRowTH IN LEBANON ${ }^{1}$}

Lebanon's growth over the last decade has lagged the MENA region and other emerging markets. A diagnostic approach following Hausman and others identifies a large infrastructure deficit, high public debt, political risks, and a weak governance and business environment as the most binding constraints to growth. Removing these constraints will be key to increasing growth and making it sustainable.

1. Lebanon's growth performance over the last decade has been mixed. Though the economy expanded on average by

4.9 percent during $2000-10$

(Figure 1), this does not compare favorably with the average growth of comparator groups (Table 1). High volatility has been the main feature of growth, with downturns - primarily caused by security incidents or regional conflicts-followed by catch-up growth.

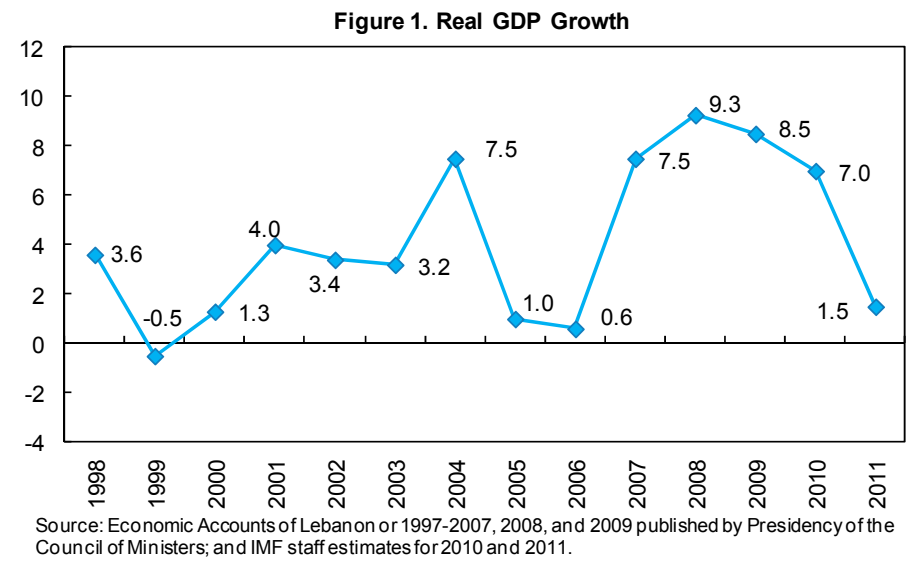

2. Lebanon faces the challenge of finding new sources of growth. The recent expansion came to an end in 2011 and potential output is estimated at around 4 percent in the medium term. Increasing potential output will require addressing the structural weaknesses that constrain growth.

Table 1. Real GDP Growth, 2000-10: Average and Standard Deviation

\begin{tabular}{lrr}
\hline & Average & Std Dev \\
\hline Lebanon & 4.9 & 3.2 \\
Emerging Market Top Performers & 6.4 & 2.8 \\
MENA & 5.2 & 3.2 \\
\hline
\end{tabular}

Sources: WEO; and IMF staff estimates.

\section{This note identifies the most binding constraints to growth in Lebanon. We} address this question by applying the growth diagnostic method following Hausman and others. ${ }^{2}$ The approach begins from the proximate causes of growth, establishes the greatest constraints to growth, and identifies the specific distortions behind them. While this approach is not new, it offers a systematic way to document constraints and whittle them down to the most binding.

\footnotetext{
${ }^{1}$ Annette Kyobe and Najla Nakhle.

${ }^{2}$ Hausman, Rodrik, and Velasco (2005).
} 
4. What are the constraints to growth in Lebanon? Hausman and others postulate that economic activity is constrained by either low returns to investment or high cost of finance. The first step is to diagnose which constraint is binding for Lebanon (Figure 2).

Figure 2. Potential Constraints to Growth

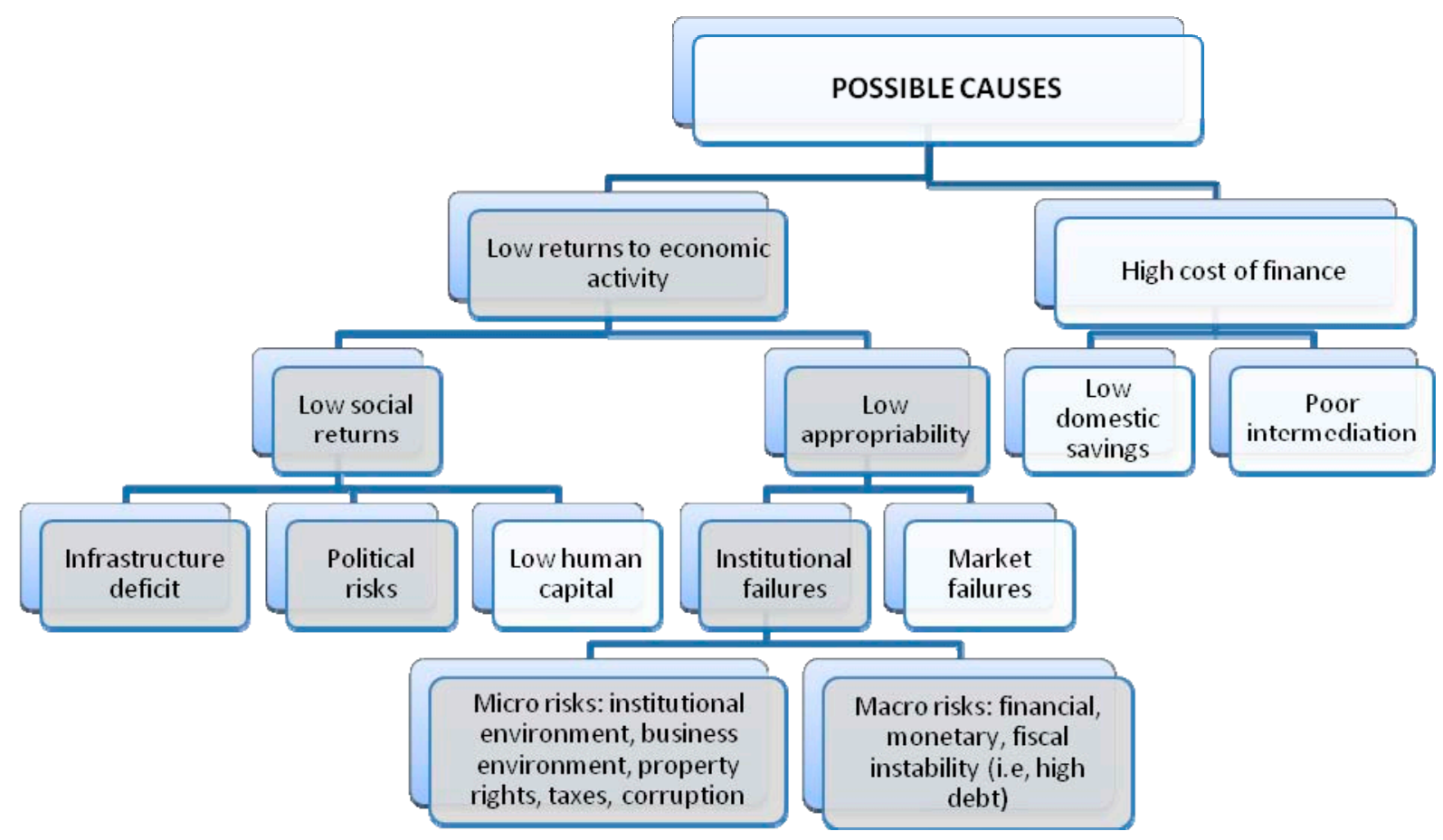

Source: Hausman and others.

\section{A. Is it High Cost of Finance?}

5. It is not the high cost of finance. If domestic savings were low, there would be a willingness to remunerate savings through higher interest rates. Though interest rates have been high over the last decade, this has reflected Lebanon's risk premium from political uncertainty and high debt levels. With the large banking sector (assets of almost 350 percent of GDP) funded by sustained deposit inflows and able to finance both the public and private sectors, crowding out of the private sector is likely to be at the margin only. Poor intermediation is also not likely a problem, as Lebanese banks have increasingly channeled their deposits to the private sector, resulting in high private sector credit growth. ${ }^{3}$ Private

\footnotetext{
${ }^{3}$ Kyobe, Nakhle, and Sadikov (2012).
} 
sector lending at 80 percent of GDP in 2010 is substantial, and the economy has a vibrant small- and medium-size enterprise (SME) sector ${ }^{4}$ (ESCWA 2007).

\section{Lebanon's financial system is inclusive compared with other MENA countries.}

Financial systems that provide access to finance to younger enterprises allow for faster growth and employment creation. On the basis of various indicators, Lebanon performs well. The World Bank's Financial Access and Stability Report from 2011 finds a positive correlation plotting private credit against the number of loan accounts per 1,000 adults. While most MENA countries fall below this regression line, reflecting poor bank penetration and limited access to credit, this is not the case for

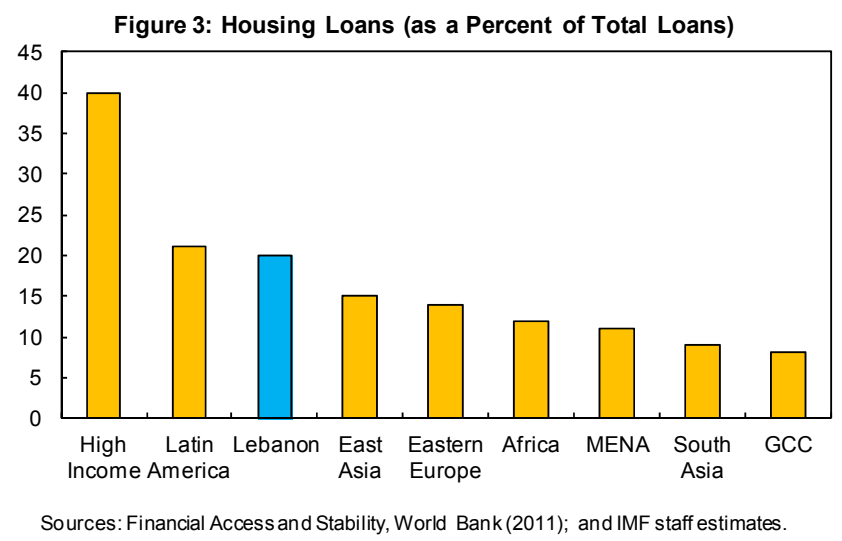

Lebanon. Compared with MENA, Lebanon has one of the lowest loan concentrations and the largest shares of SME loans in total loans. At 16 percent in 2009, loans to SMEs are on par with middle-income countries, and much higher than the MENA average of 7 percent (World Bank, 2011a). Consistent with this story, survey data find that SMEs do not identify access to finance as a constraint to doing business. In fact, 70 percent of firms have access to a line of credit, which compares favorably to the regional average of 20 percent; and 50 percent of firms use banks to finance expenses while the regional average is 24 percent (World Bank, 2011b). Long-term financing (i.e., housing finance) is also well developed (20 percent of total loans) compared to MENA and other regions (Figure 3).

\section{B. Is it Low Returns to Economic Activity?}

\section{Low returns to economic activity due to both low social returns and low} appropriability appear to be a problem. Low social returns can be due to high production costs, while low appropriability occurs when producers are unable to capture a significant part of the wealth they create due to distortions such as high taxes, corruption, or poorly defined or protected property rights.

\footnotetext{
${ }^{4}$ Small and medium enterprises (defined as employing less than 200 employees and with sales of less than US $\$ 5$ million per year) constitute more than 90 percent of enterprises and employ 94 percent of the labor working in enterprises.
} 


\section{Is it low social returns?}

\section{Lebanon has an infrastructure deficit and high political risks which depress}

social returns. Poor infrastructure lowers not only social returns, but also private investment returns due to lack of complementary public inputs. Domestic and external political risks create uncertainty about the environment in which projects will be undertaken, inhibiting investment and growth. Low human capital accumulation, however, is not considered a key contributor to low social returns in Lebanon. Despite some evidence that firms identify labor skills as a constraint to business, the Lebanese workforce is highly educated as reflected in high adult literacy and the availability of scientists and engineers, owing to good access to education (as measured by high enrolment rates). Thus, while there may be some skills mismatch, low human capital is not considered a problem.

\section{Infrastructure Deficit}

9. Lebanon's infrastructure bottlenecks are severe. According to the World Economic Forum's Global Competitiveness Index (GCI), Lebanon ranks 115 on the quality of roads and 135 on the overall quality of infrastructure among 140 countries.

- $\quad$ Poor road network. Lebanon has around 7,200 km of roads, many of which are in need of maintenance and repair. Despite somewhat better road conditions than in suburban and rural areas, Beirut suffers from traffic congestion due to weak traffic management, further exacerbated by heavy reliance on private transportation.

- $\quad$ Costly and unreliable electricity. The state-owned electricity company is highly inefficient, while tariffs - unchanged since 1996 - do not reflect actual production cost. Years of underinvestment led to systemic power shortages, estimated at $700 \mathrm{MW}$ (50 percent of current capacity). Outages are frequent and much of the excess demand is met by costly private generators, adversely affecting the competitiveness of the economy, especially the energy-intensive manufacturing sector.

- $\quad$ Poor water supply. The water and sanitation sector is unable to meet demand leading to intermittent public water supply. Though private water supply now accounts for 75 percent of total household water consumption, it is costly and some areas are underserved (World Bank, 2010).

- $\quad$ Expensive and underdeveloped communication infrastructure. With 31 internet users and 69 mobile subscriptions per 100 inhabitants, Lebanon ranked $10^{\text {th }}$ and $14^{\text {th }}$, respectively, out of 17 countries in the region, and $100^{\text {th }}$ and $144^{\text {th }}$ out of 233 
countries worldwide in 2010. ${ }^{5}$ In addition to low penetration, Lebanon's Internet and Communication Technology (ICT) services are among the most expensive and least competitive in the region. ${ }^{6}$

\section{Political Risk}

\section{Political risks reflect a fragmented political system and regional tension.}

Lebanon scores poorly on political risk compared to most other emerging markets (Figures 4 and 5). ${ }^{7}$ More recently, risks have increased owing to the regional unrest, particularly in Syria. Since 1990, Lebanon has gone through fifteen governments (the average life of each less than two years), political assassinations, and a volatile external environment (military conflicts with Israel in 1996, 2000, and 2006). ${ }^{8}$
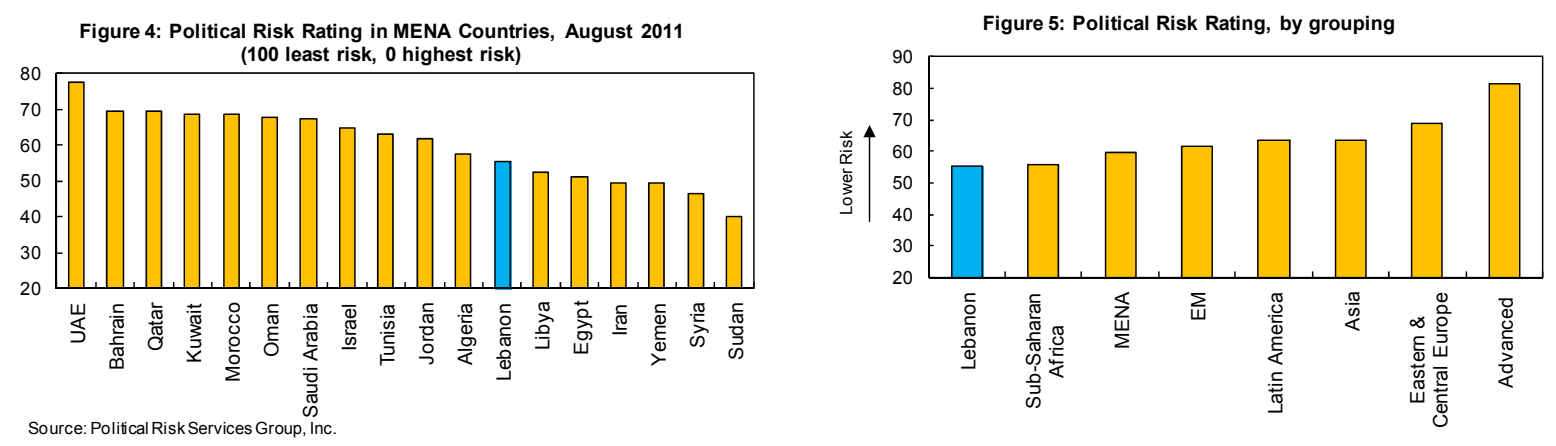

\section{Is it low appropriability?}

\section{Difficulty in appropriating resources reflects largely institutional failures.}

Market failures are not a relevant constraint for Lebanon because of its capacity for innovation and the private sector's ability to identify profitable products for investments. ${ }^{9}$ The main constraints come rather from institutional failures at the micro and macro levels. On the micro side, the likely source of risks is a poor business and governance environment.

\footnotetext{
${ }^{5}$ International Telecommunications Union (Bank Audi, 2011) and IMF staff calculations.

${ }^{6}$ The Arab Advisors Group and Cellular Competition Intensity Index (Bank Audi, 2011). The index takes into account the number of operators, packages, and services available.

${ }^{7}$ The political risk rating by the Political Services Group captures domestic political stability. It is an index covering twelve components: government stability, socioeconomic conditions, investment profile, external and internal conflict (together comprising 60 percent of the weight in the index) and corruption, military politics, religious tension, law and order, ethnic tensions, democratic accountability and bureaucratic quality.

${ }^{8}$ The 2006 war with Israel is estimated to have cost 10 percent of GDP in destroyed public and private property and reduced trade and tourism, according to World Bank (2007).

${ }^{9}$ Global Competitiveness Index, World Economic Forum (2011).
} 
A good environment in general provides equitable provision of services and access to resources, while a weak environment fosters corruption, political instability or government ineffectiveness, which handicaps entrepreneurship and decreases private investment returns. Taxes are not seen as a major constraint in Lebanon because the country has one of the lowest corporate tax rates in the region and the 10 percent value-added tax is moderate by regional standards. While property rights are not a major constraint, corruption is perceived as one. Transparency International ranked Lebanon $127^{\text {th }}$ out of 180 countries with a Corruption Perception Index of 2.5 in $2010 .^{10}$ On the macro side, Lebanon has maintained financial and monetary stability, but carries a high debt. A debt level among the highest in the world, substantial rollover needs for the government, and a large exposure of banks to the sovereign present persistent risks to macroeconomic stability and thus growth.

\section{Business Environment}

12. The business environment is poor. Lebanon ranks $113^{\text {th }}$ out of 183 countries and $11^{\text {th }}$ out of 18 MENA countries on the World Bank's Doing Business indicators (DB). The rankings cover the nine steps to set up, operate and close a business. Results are based on rules and regulations as they appear on paper, but practice differs. For example, the World Bank's Business Environment and Enterprise Performance Surveys (BEEPS) question firms on the business environment and find that it takes close to 80 days to open a business in Lebanon, not 11 days as reported by DB (Figure 6). Responses to

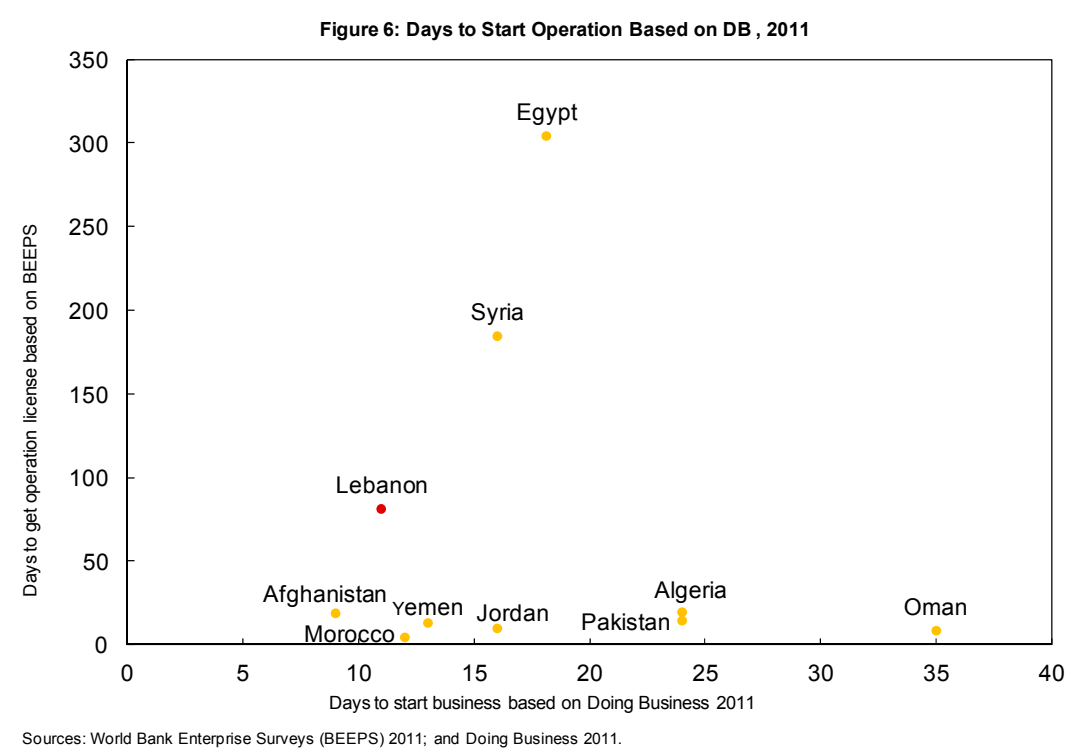
BEEPS also provide a way to assess the access of firms to government services. In Lebanon, while DB suggests it should take firms only 15 days or less to get a license, the median firm in the survey received its license in 60 days, while 10 percent of firms received it in 179 days

\footnotetext{
${ }^{10}$ The index ranks countries by their perceived levels of corruption, as determined by expert assessments and opinion surveys on the scale and frequency of bribery among public officials. The index ranges from 0 to 10 , with 0 being most corrupt.
} 
(Figure 7). Such a large variation could be indicative of preferential treatment and a weakness in the business environment.

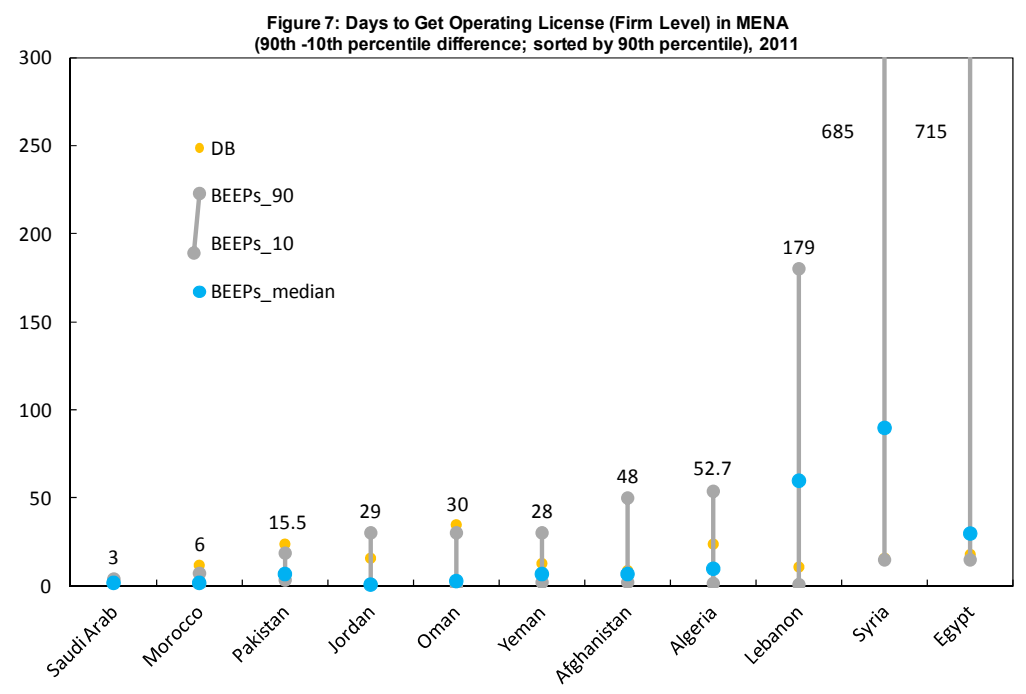

Sources: World Bank Enterprise Surveys (BEEPS) 2011; and Doing Business 2011.

\section{Governance}

\section{Lebanon has the seventh} lowest rank on governance among 18 MENA countries (Figure 8). Very broadly, governance includes the capacity of the government to effectively formulate and implement sound policies. Lebanon's low score comes from lack of political stability, weak control of corruption, and low government effectiveness.

\section{High Debt}

\section{Lebanon is saddled} with high debt. At 137 percent (end-2010), Lebanon's government debt-to-GDP ratio is among the highest in the world. Literature finds that high public debt is associated with lower growth rates. Reinhart and Rogoff (2010) show that emerging countries' growth declines
Figure 8: MENA Countries Average Percentile Rank on World Governance Indicators, 2009

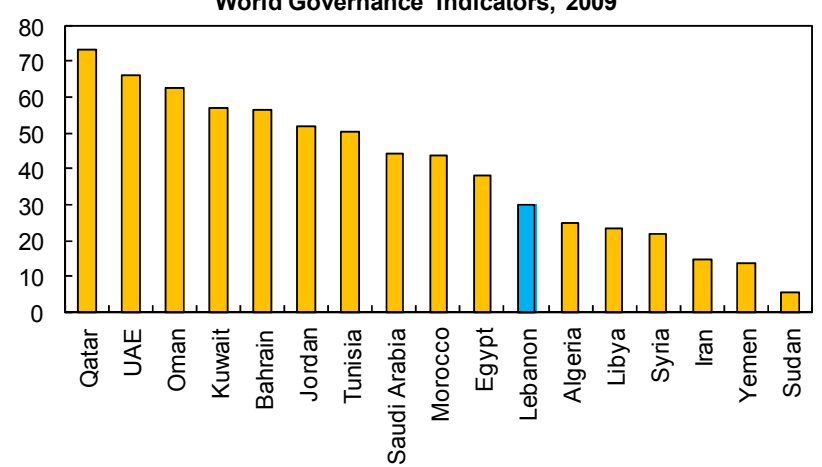

Source: IMF staff calculations based on World Bank's World Development In dicators .

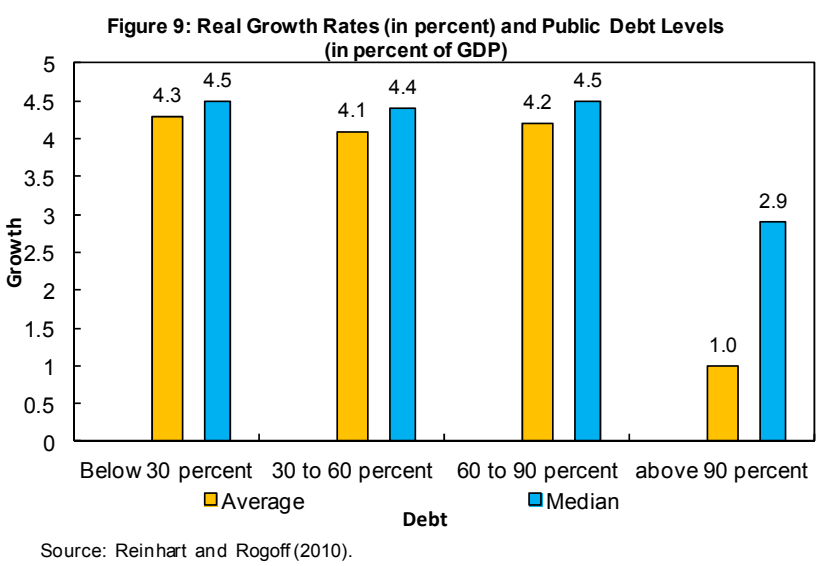


substantially once debt exceeds 90 percent of GDP (Figure 9). ${ }^{11}$ High interest outlays, averaging 13 percent of GDP in 2000-10, limit fiscal space thus making it difficult for the government to make the investments needed to address the infrastructure deficit (Figures 10 and 11). High debt also threatens macroeconomic stability - critical for confidence and private investment. Risk associated with high debt potentially increases interest rates and the cost of financing for the private sector (though not the availability of financing in Lebanon).
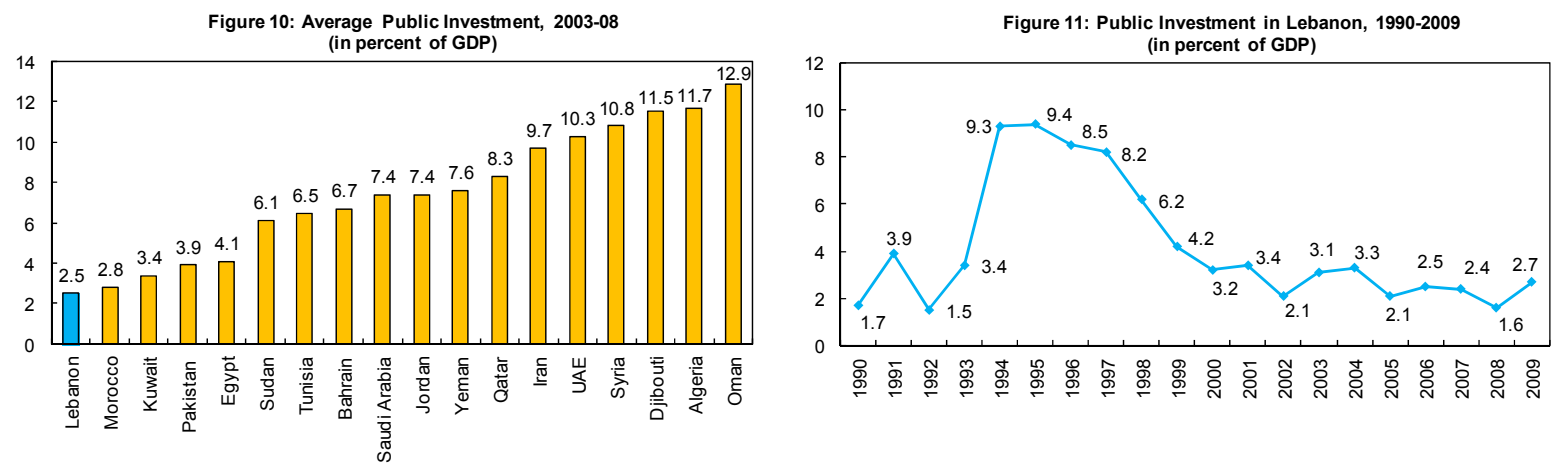

\section{The binding constraints}

\section{identified in this note are consistent} with those reported by the World Economic Forum. Among a group of 142 countries, Lebanon ranks $89^{\text {th }}$ on the GCI, behind emerging markets and the MENA average (Figure 12). ${ }^{12}$ The low rankings are driven by government instability, inadequate supply of infrastructure, and an inefficient government bureaucracy.

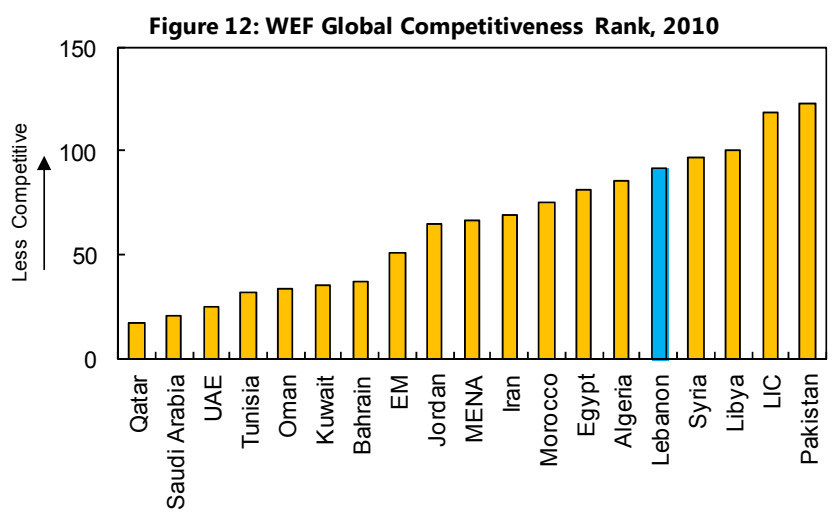

Source: World Economic Forum's Global Competitiveness Indicators' (GCl) Rank (2010).

\footnotetext{
${ }^{11}$ Reinhart and Rogoff (2010).

${ }^{12}$ The GCI ranks countries based on survey data across 12 "pillars" of competitiveness: institutions, infrastructure, macroeconomic environment, health and primary education, higher education and training, good market efficiency, labor market efficiency, financial market development, technological readiness, market size, business sophistication, and innovation.
} 


\section{Conclusion}

16. Reforms should remove the most binding constraints to growth. Advancing these reforms will require building consensus and therefore time. In the short term, the authorities could focus on measures they can implement quickly.

- Infrastructure. Recent improvements in the provision of ICT services and the parliament's approval of investments in the electricity sector are welcome. Scaling-up investment in infrastructure, especially electricity, must go in parallel with structural reforms so as to make gains long-lasting and safeguard fiscal sustainability.

- Business environment and governance. Transparent enforcement of rules and regulations (i.e., what is on paper happens in practice), reduction in red tape, improvements in the judicial system, modernization of legislation, and upgrading of information technology for public services (i.e., electronic applications) could decrease the perception that the bureaucracy is inefficient.

- Debt. The medium-term agenda should target a sizeable reduction in the debt-to-GDP ratio, while creating fiscal space for higher investment and targeted spending to the poor. This could be achieved by making the tax regime more efficient and equitable, while rationalizing expenditure. 


\section{References}

Bank Audi, (2011) Lebanon Weekly Monitor, Issue 29.

Bhattacharya R. and H. Wolde, (2010) "Constraints on Growth in the MENA region," IMF Working Paper.

Economic and Social Development Commission in Western Asia, (2007) "The Integrated SME Support Program," available at: http://css.escwa.org.lb/sdpd/presentations/34Nov07/2-4-Lebanon.pdf

Hausman, R., Rodrik D., Velasco, A., (2005) “Growth Diagnostic,” Reproduced, Harvard University.

International Finance Corporation, (2012) "Doing Business, Economy Profile: Lebanon.”

Kyobe, A. Nakhle, N. and A. Sadikov, (2012) "Private Sector Credit Growth in LebanonSupply or Demand Driven?,"Lebanon-Selected Issues, Chapter 1.

Reinhart C. and K. Rogoff, (2010) "Growth in a Time of Debt," American Economic Review Papers and Proceedings.

The World Bank, (2011a) “A Road Map for the Middle East and North Africa," Financial Access and Stability Report.

— (2011b) Enterprise Survey. , (2010) "Republic of Lebanon Water Sector: Public Expenditure Review." , (2007) “Exploring Lebanon's Growth Prospects,” MENA Region, Social and Economic Development Group. 


\section{Poverty, Social Safety Net, ANd Subsidies in Lebanon ${ }^{1}$}

Poverty rates are high with significant regional disparities. Lebanon's social safety net and subsidies are costly, badly-targeted, and fragmented. Focus should be on gradually replacing universal subsidies with cost-effective and well targeted ones, especially in the electricity sector. There is also room for narrowing the scope of some subsidies and integrating new programs with existing ones. Data gaps on social indicators should be addressed. A communication strategy would help shore up broad support for reforms.

\section{Poverty incidence in}

\section{Lebanon is high, showing significant} regional and sectoral disparities.

Nearly 20 percent of the population in 2004-05 could be considered as poor and 8 percent as extremely poor (UNDP, 2008). ${ }^{2}$ Poverty is concentrated in peripheral regions (i.e., outside Beirut, in the North and in the South), with 40-50 percent of the population in these regions considered as poor (Figure 1). The poor are mostly unskilled workers (e.g., in sectors such as agriculture and construction) and unemployed.

\section{Inequality measured by the Gini} index is below that in other middle income countries but comparable to the median for MENA (Table 1). The share of consumption by the lowest quintile of the population, estimated at 7 percent of all consumption (UNDP, 2008), is higher than the median of upper middle income countries. It though is slightly below that of MENA countries with a similar (or slightly higher) Gini index (Jordan and Yemen).

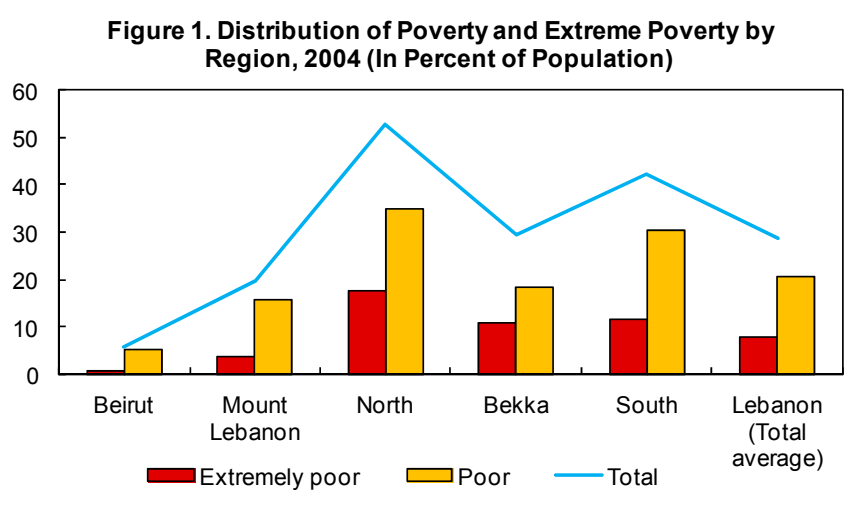

Source: Ministry of Social Affairs and the United Nations Development Programme (2008).

\begin{tabular}{|c|c|c|c|}
\hline \multicolumn{4}{|c|}{$\begin{array}{l}\text { Table 1. Gini Index and Income Shares Held by the } \\
\text { Poorest and Richest Quintiles (In Percent) in Selected } \\
\text { MENA Countries, Various Years }\end{array}$} \\
\hline Year & Gini index & $\begin{array}{l}\text { Income } \\
\text { share } \\
\text { held by } \\
\text { highest } \\
20 \%\end{array}$ & $\begin{array}{c}\text { Income } \\
\text { share } \\
\text { held by } \\
\text { lowest } \\
20 \%\end{array}$ \\
\hline \multicolumn{4}{|l|}{ Selected MENA Countries } \\
\hline Egypt & 32.1 & 41.5 & 9.0 \\
\hline 2005 & 38.3 & 45.0 & 6.4 \\
\hline Jordan & 37.7 & 45.4 & 7.2 \\
\hline Lebanon 1/ & 37.0 & 43.0 & 7.0 \\
\hline Morocco & 40.9 & 47.9 & 6.5 \\
\hline Syria & 35.8 & 43.9 & 7.7 \\
\hline Tunisia & 40.8 & 47.2 & 5.9 \\
\hline Yemen & 37.7 & 45.3 & 7.2 \\
\hline Median & 37.7 & 45.1 & 7.1 \\
\hline \multicolumn{4}{|l|}{ Memo items: } \\
\hline Median Upper Middle Income 2/ & 42.4 & 48.6 & 5.7 \\
\hline Median Emerging Markets 3/ & 41.2 & 47.8 & 5.9 \\
\hline \multicolumn{4}{|c|}{ Source: World Bank (2011a); and UNDP (2008). } \\
\hline \multicolumn{4}{|c|}{$\begin{array}{l}\text { 1/ For Lebanon, data refer to consumption shares due to lack of data on } \\
\text { income shares. }\end{array}$} \\
\hline \multicolumn{4}{|c|}{$\begin{array}{l}\text { 2/ Based on the World Bank's income group clasification, for which data are } \\
\text { available from } 2005 \text { onwards. Years vary by country. }\end{array}$} \\
\hline \multicolumn{4}{|c|}{$\begin{array}{l}3 / \text { Refers to countries for which data are available from } 2005 \text { onwards. Years } \\
\text { vary by country. }\end{array}$} \\
\hline
\end{tabular}

\footnotetext{
${ }^{1}$ Asmaa El-Ganainy and Najla Nakhle.

${ }^{2}$ The dollar equivalent for the poverty line (when converted at the official exchange rate) is US\$4 per capita per day, and for the extreme poverty line is US\$2.40 per capita per day.
} 


\section{A. Lebanon's Social Safety Net and Subsidies}

3. The social safety net and subsidies amounted to about 4 percent of GDP in 2010 (Table 2). ${ }^{3}$ The following sub-sections describe the various components of the safety net and subsidies and compare them to other countries in the region.

\section{Social safety net}

\section{The social safety net provided} through official channels is small. ${ }^{4}$ Since the mid-2000s, social spending, including on health, education, and pensions ranged between 30-40 percent of primary spending (about $7 \frac{1}{2}$ percent of GDP) (Figure 2). For 2010, this would place Lebanon broadly within the average in other MENA countries.

However, the share allocated to the social safety net (defined as non-contributory transfers targeted to the poor)
Table 2: Cost of Social Safety Nets and Various Subsidy Schemes, 2010 (In percent of GDP)

\begin{tabular}{|c|c|c|}
\hline & & Cost \\
\hline \multirow{6}{*}{ 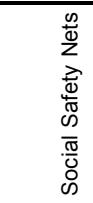 } & Social services $1 /$ & 0.20 \\
\hline & Fee waiver for hospitalization & 0.57 \\
\hline & Price subsidies: & 0.23 \\
\hline & Diesel subsidy & 0.10 \\
\hline & Tobacco subsidy $2 /$ & 0.08 \\
\hline & Bread subsidy & 0.05 \\
\hline \multicolumn{2}{|c|}{ Total cost of social safety net programs } & 1.0 \\
\hline \multirow{4}{*}{$\begin{array}{l}0 \\
\frac{0}{0} \\
\frac{0}{w} \\
\stackrel{0}{3} \\
\omega\end{array}$} & Transfers to EdL & 2.92 \\
\hline & Wheat subsidy & 0.03 \\
\hline & Sugar beet subsidy & 0.00 \\
\hline & Agricultural export subsidy & 0.08 \\
\hline
\end{tabular}
Total cost of subsidies

\begin{tabular}{l|l}
\hline Total cost of all programs & 4.0 \\
\hline
\end{tabular}
Sources: Lebanese authorities; World Bank estimates; and IMF staff calculations. $1 /$ Data refer to 2010 budgetary allocations.

2/ Preliminary estimate of about LL 46 billion.

is less than one percent of GDP. This is small by international standards, which are about 2 percent of GDP on average, with a median of about 1 1/2 percent of GDP (Weigand and Grosh, 2008). Social safety net spending in Lebanon is also lower than the historical average in selected MENA countries, estimated at about 1.7 percent of GDP (Figure 3).

\footnotetext{
${ }^{3}$ This excludes programs funded through contributions, such as the ones run by the National Social Security Fund, including health insurance and the family allowance programs. It also excludes an interest subsidy, which amounted to 0.2 percent of GDP in 2010 and is administered by the Banque du Liban (Kyobe, Nakhle and Sadikov, 2012).

${ }^{4}$ The informal social safety net provided by civil society and non-governmental organizations (NGOs) is substantial. They provide various forms of social services, including in basic health care, education, training, and microfinance.
} 


\section{The official social safety} net is provided through three channels. These are (i) social services to specific vulnerable groups, such as delinquents, disabled persons, orphans, and school dropouts, run by the Ministry of Social Affairs through welfare institutions and NGOs;

(ii) fee waivers for

hospitalizations, which provide for 85 percent of the fee for using private hospital services for those who do not have any insurance coverage; this program is managed by the Ministry of Public Health; and (iii) price subsidies for diesel, tobacco, ${ }^{5}$ and bread (Box 1). More than half of the funds go to fee waivers for hospitalization and the rest is about equally split between the Ministry of Social Affairs' services and price subsidies.

\section{Subsidies for energy and selected agricultural products}

\section{There are price}

\section{subsidies for energy. The}

subsidy provided to Electricité du Liban (EdL) mainly pays for the difference between the cost of electricity production at the actual oil price and the "subsidized" price of $\$ 21$ per barrel (set in 1996), but also for EdL's operation and maintenance costs and nontechnical losses. Through this, the government indirectly subsidizes electricity consumption by keeping tariffs below cost recovery. ${ }^{6}$

\footnotetext{
${ }^{5}$ The tobacco subsidy is considered part of the social safety net because the tobacco industry is a major source of income for many people in rural areas where poverty is widespread. The Bank estimates that over 45,000 Lebanese at least partially depend on tobacco cultivation for their livelihood.

${ }^{6}$ In 2006, EdL's average tariff was 9.4 US cents $/ \mathrm{kWh}$, a level which is at the higher end for the region, but comparable to that of countries which rely on imported fuel for power generation (such as $10 \mathrm{US}$ cents $/ \mathrm{kWh}$ in Morocco and 7 US cents/kWh in Jordan) (World Bank, 2008).
}

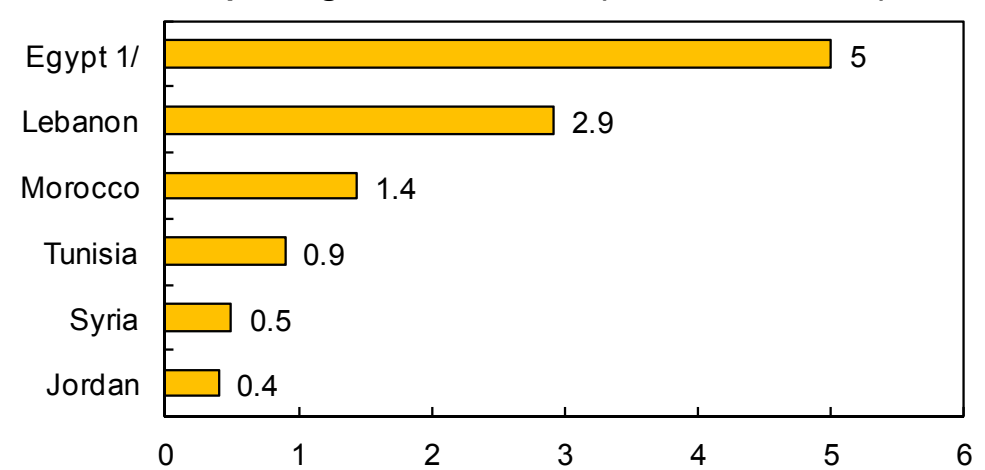

Sources: IMF country team estimates; and Lebanese Auth orities. 1/Datafor Egypt refer to FY2010/11.
Figure 3. Social Safety Nets Expenditures in of GDP)

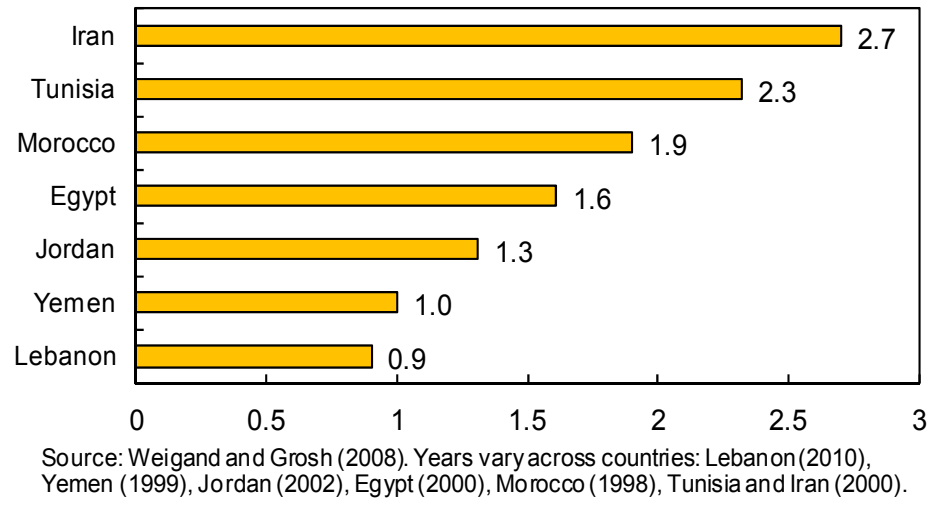




\section{Box 1. Price Subsidy Schemes}

\section{Consumers subsidies}

Diesel fuel subsidy (also "mazout" or "winter fuel" subsidy). Direct beneficiaries are large petroleum stations that are supposed to pass it on to consumers. This subsidy reduces the price of diesel for heating houses during December-March. The price of a 20 liter tank of diesel is subsidized by a fixed amount provided that the subsidized price remains above a certain floor.

Bread subsidy. This subsidy was introduced in July 2007 in response to food price increases. It was provided to millers to purchase imported wheat for milling and Arabic bread making. It caps the price of bread at a certain level per pack. The program was stopped in 2008 when international wheat prices fell, but was re-introduced in 2010 .

\section{Producer subsidies}

Wheat (producer) subsidy. This subsidy is provided to farmers to encourage local wheat production. The government purchases wheat from farmers at guaranteed prices and sells it at a lower price. All wheat farmers are eligible to participate but the size of the subsidy per farmer is capped in relation to the size of the cultivated area to limit subsidies on smuggled wheat. The subsidy has been used on and off. For instance, when wheat prices increased in 2007, most farmers sold their production directly to millers, not necessitating the subsidy.

Tobacco subsidy. Beneficiaries are tobacco farmers. The public monopoly, Régie de Tabac (RdT), purchases all tobacco production at subsidized prices from local farmers, who can only sell the amount demanded by RdT and are not allowed to sell more than their quota. The subsidy is recouped by RdT through tobacco taxes and other charges paid by foreign tobacco producers.

Sugar beet subsidy. Beneficiaries are sugar beet farmers (about 200 in 2008). The subsidy is based on an assumed cultivation area. All beets are sold on the domestic market. The subsidy was phased out in 2008 , but a retroactive payment was made in 2009 for the subsidy provided in 2006 .

Agricultural exports subsidy. The government introduced the "Export Plus" program in 2001, under which it subsidizes the export of specific agricultural products, including fruits, vegetables, flowers, olive oil, and honey. Beneficiaries are agricultural exporters who buy products from farmers. The subsidy amount depends on the product, the export destination, and mode of transportation. The program was supposed to be phased out gradually starting in 2006 and expire by end 2010, but was extended to October 2011. A Ministerial Committee is currently revising the program (changes are expected to be broadly cost neutral compared with 2010). 
Transfers to EdL amounted to about 3 percent of GDP in 2010, which is higher than the average of about 2 percent of GDP in oil importing MENA countries (Figure 4). Residents of Beirut, which has the lowest poverty rate in the country, are its main beneficiaries. ${ }^{7}$

7. Electricity sector subsidies are supplemented by other measures. There is a history of changing the pricing structure of gasoline to reduce the impact of rising fuel prices by cutting the excise tax. ${ }^{8}$ Moreover, on October 5, 2011, Parliament approved one-off cash support to taxi drivers equivalent to the value of 250 liter of gasoline per month and conditional on the price of a tank exceeding a specific threshold. The support is for three months (subject to a possible renewal for another three months) with an estimated cost of 0.1 percent of GDP; its implementation is pending.

8. There are also producer subsidies, but these are small. These subsidies are for wheat, sugar beets, and agricultural exports (Box 1 and Table 2). Total cost was 0.11 percent of GDP in 2010, ranging from almost negligible (the sugar beet subsidy which was phased out in 2008) to about 0.08 percent of GDP (the agricultural export subsidies).

\section{B. Weaknesses in the Social Safety Net and Subsidies}

9. Targeting is generally weak with limited benefits for poor households. Lebanon relies largely on generalized subsidies, which are relatively easy to administer, but tend to benefit the well-off, while targeted subsidies are less costly and can be very effective in fighting extreme poverty (see Box 2 for an example). Only the white (Arabic) bread subsidy, which was eliminated in 2008 following the fall in international wheat prices but re-introduced in 2010, appears relatively efficient in terms of targeting: The poorest 40 percent of the Lebanese population receive about half of total spending on the subsidy (Figure 5) - a result that could largely be explained by the fact

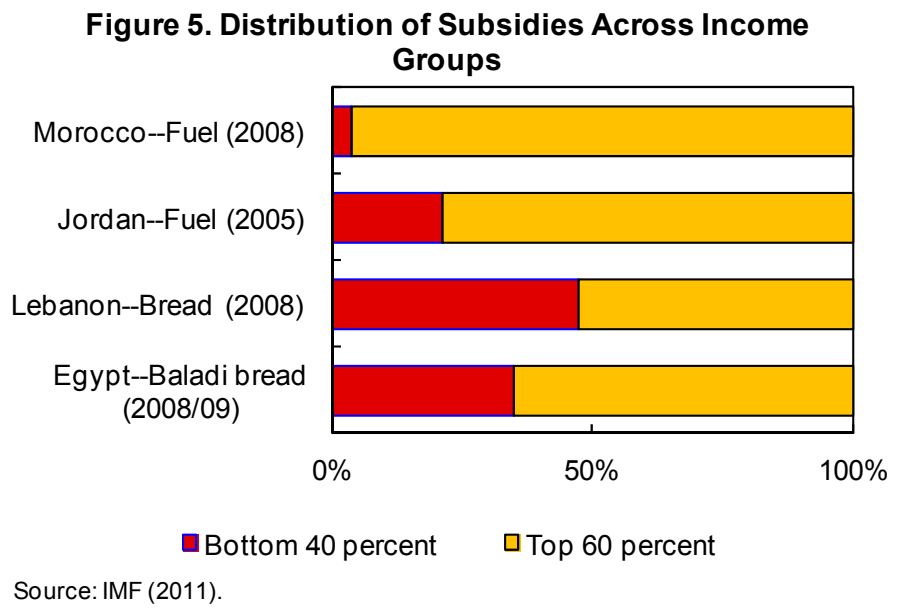

\footnotetext{
${ }^{7}$ EdL expenditure is far higher in Beirut than in other regions, reflecting both higher consumption because of higher incomes of Beirut households and the lower electricity rationing in the city (World Bank, 2009).

${ }^{8}$ The government cut excise taxes on gasoline in May 2004. Revenue losses in 2006-08 were estimated at 2 percent of GDP. The cut was reversed in 2009, but in February 2011 the government cut excises again, this time in half, with budgetary costs of up to one percent of GDP annually.
} 
that low income households allocate a larger share of their total consumption to this type of bread.

\section{Box 2. Brazil's Bolsa Família Program}

The Bolsa Familia is Brazil's conditional cash transfer program launched in 2003 in support of the Brazilian "Zero Hunger Initiative" (World Bank, 2011b). Similar schemes are used in other countries, including Indonesia, Morocco, South Africa, and Turkey. The program directly transfers about US $\$ 35$ dollars per month to poor families with children conditional on education and health targets, mainly regular school attendance and medical check-ups.

The Bolsa Familia is well targeted. It targets people that did not benefit from social programs. The poorest 40 percent of the population receives 94 percent of the funds which are mostly used to buy food, clothes and school supplies.

Bolsa Familia has been very effective. It contributed to the decline in extreme poverty from 22 percent in 2003 to 7 percent of the population in 2009. At least 12.7 million families, or some 50 million people, benefited from the program. The second phase of the program started in September 2010 and is expected to last for five years. The expected outcomes are that at least three quarters of families in the 20 percent poorest group get Bolsa transfers toward achieving school attendance of at least 90 percent of primary-age school children in extremely poor families and substantial improvements in health indicators.

Three factors contributed to the success of the program: strong political support, a robust monitoring and evaluation system, and capacity to innovate. Bolsa Familia developed a strong monitoring and evaluation system even though it was coordinated by three ministries and implemented through more than five thousand municipalities. A major innovation in this system was the introduction of performance-based incentives for municipalities.

\section{Services are provided by different agencies with little coordination. Social} components are included in various sectoral strategies, but with little harmonization among the sectors, ministries, and providers, possibly reflecting a sectarian balance. For instance, most of the social services that are financed through the Ministry of Social Affairs are provided by a range of welfare institutions and NGOs contracted by the ministry, resulting in overlaps and administrative inefficiency. 


\section{Some elements give rise to waste and distortions.}

- The hospitalization program is subject to leakages and weaknesses. The Ministry of Public Health performs the role of "insurer of last resort" for individuals who are not covered by any insurance scheme (estimated at half of the population). Weaknesses largely stem from poor supply and demand incentives, which resulted in increasing reliance on specialists and expensive health technologies and procedures at the expense of more cost-effective primary health care services and health prevention interventions. On the supply side, the Fee for Service system, which is the basis for reimbursing health providers, is geared to produce more (and expensive) services than needed, leading to abuse and higher costs. As a result, actual costs exceed budget allocations. Some of the reimbursements to hospitals are thus delayed, resulting in reluctance to admit Ministry of Public Health patients. This in turn results in delay of care, eventual hospitalization with more severe illness, and ultimately higher costs. On the demand side, demand for primary health care is low because patients tend to visit specialists instead of family physicians as a first recourse (Ministry of Social Affairs, 2011).

- There is abuse of some subsidies. Because the diesel subsidy is provided only during the winter, anecdotal evidence suggests that petroleum stations buy large quantities of subsidized diesel and stock them to be sold at higher prices during April-November when the subsidy is not provided. Smuggled wheat from neighboring countries could benefit from the wheat subsidy. Also, there are indications that the subsidized flour is used for products that are not in the consumption basket of the poor (e.g., pizza bread, pasta, and French pastry).

- Other subsidies distort production. The tobacco subsidy hampers the development of the sector, because farmers have no incentive to increase their production and/or raise quality to international standards. Agricultural export subsidies encourage producers to increase their production toward exports markets, which could result in higher prices for domestic consumers possibly affecting the lowest income quintile most severely.

12. Governance is weak. There is a lack of reliable poverty indicators and thus outcomes of interventions, including ex-post evaluations. There also is a lack of service standards. Experience from other countries suggests that a strong monitoring and evaluation system is critical to the success of targeting programs (Box 2). 


\section{Ongoing Reforms}

13. The government developed a Social Action Plan in 2007. As part of the Paris III donor conference, the Plan aims at reducing poverty, improving social indicators, and achieving the Millennium Development Goals by 2015. It also includes a medium-term strategy to introduce safety net programs, such as cash transfers to the very poor households; school meals and books, stationary, and transportation facilities to students living in poor households; and free hospitalization for all households under the poverty line (Republic of Lebanon, 2007). Evolving from this Plan through a participatory process, the National Social Development Strategy was launched in 2011. The Strategy identified five key objectives toward poverty reduction: achieving better health; strengthening social protection; providing quality education; improving opportunities for equitable and safe employment; and revitalizing communities and developing the social capital.

\section{As part of the Social Action Plan, the National Poverty Targeting Program} (NPTP) was launched in 2010. It started with a pilot in 2009 with the objective of establishing a targeting mechanism that could be used to deliver social transfers and services to the poor and vulnerable using a proxy means testing (PMT) targeting system. The pilot covered some 25,000 people and assisted in developing applications and questionnaires as well as manuals. Work is in progress to use the PMT to establish a program of direct cash assistance for the extreme poor. According to simulations by the Bank, such assistance, if well-implemented, is cost-effective, ${ }^{9}$ and has a large impact on alleviating poverty. ${ }^{10}$

\section{Preparations are in their final stages to launch a rollout of the pilot. A public} relations campaign has been recently launched to ensure that eligible households, estimated to reach 300,000, will visit some ninety Social Development Centers that have already been set up. The Central Administration of Statistics is conducting a survey to update the Living Conditions of Households. This will help in updating the scores of the PMT for the NPTP and serve as a baseline for reporting the impact of the program on poverty reduction. The government plans to distribute the first payments to eligible beneficiaries by mid- 2012 .

\footnotetext{
${ }^{9}$ International experience with the PMT targeting system suggests that these programs could increase the proportion of transfers accruing to the bottom two income quintiles to over 60 percent.

${ }^{10}$ The World Bank estimates that to reduce extreme poverty by half by 2015 , about 0.3 percent of GDP would be needed annually. The benefits would reach about 330,000 people, with an average benefit size of about LL 448 thousands per beneficiary.
} 


\section{Conclusion}

\section{Reforms should focus on:}

- Developing the social safety net, while gradually replacing universal subsidies with cost-effective and well-targeted ones. The EdL subsidy is by far the largest and deserves the most attention. Changes in the subsidy must be preceded by reforms and investment in the electricity sector, with a view to improving the quality and reliability of the service, while gradually increasing electricity tariffs to cost recovery levels. Reducing the EdL subsidy would create fiscal space for the NPTP (possibly offsetting some of the adverse impact of the tariff increase on the poor), other social and infrastructure spending, and a reduction in debt.

- Narrowing the scope of existing subsidies to those that are most important for the poor (e.g., bread subsidy), and gradually replacing subsidies that are associated with negative externalities (e.g., tobacco subsidy) for more cost-effective and less distortionary ones.

- Integrating new programs with existing ones. The NPTP could be integrated with labor market programs, such as those run by the Ministry of Social Affairs and NGOs, as a way to encouraging graduation from social assistance toward access to income generating activities, micro-credit and banking services. The NPTP could also be linked to other social interventions (e.g., health and education) in the form of a conditional cash transfer to improve social outcomes and break the cycle of intergenerational poverty transmission (as was the case in the Bolsa Familia). In this regard, one could consider linking cash transfers to education targets - particularly to reduce high dropout rates - and health conditionalities - particularly to provide access to health care services for uninsured individuals who cannot afford to buy insurance.

- $\quad$ Garnering public support and buy-in for reforms through a public awareness campaign. This would require collecting and disseminating information about costs and benefits of subsidies. Vulnerable segments of the population affected by reforms may have to be compensated during a transition phase, especially because the social safety net is small, though such compensation would ultimately have to be rolled into targeted subsidies.

- Improving data availability and timeliness for social indicators, including among others, on poverty rates, income and consumption shares, and inequality indices. These efforts would greatly facilitate policy-making in well targeting the safety net. 


\section{References}

International Monetary Fund, (2011) "Moving from Subsidizing Products to Protecting People," In Regional Economic Outlook: Middle East and Central Asia Department, Chapter 3, Section 2, April 2011.

Kyobe, A. Nakhle, N. and Sadikov, A., (2012) "Private Sector Credit Growth in LebanonSupply or Demand Driven?," Lebanon-Selected Issues, Chapter 1.

Ministry of Social Affairs, (2011) "National Social Development Strategy of Lebanon."

Ministry of Social Affairs and the United Nations Development Programme, (2008)

"Mapping of Human Poverty and Living Conditions in Lebanon 2004," available in Arabic at: http://www.undp.org.lb/communication/publications/index.cfm

Republic of Lebanon, (2007) "Republic of Lebanon: Social Action Plan - Toward Strengthening Social Safety Nets, and Access to Basic Social Services," available at: http://www.rebuildlebanon.gov.lb/images_Gallery/SocialActionPlanEnglishEn22010 7.pdf

The World Bank, (2011a) “World Bank Development Indicators Database.”

, (2011b) "Bolsa Família: Changing the Lives of Millions in Brazil," (downloaded in June 2011) available at: http://web.worldbank.org/WBSITE/EXTERNAL/COUNTRIES/LACEXT/BRAZILE XTN/0, contentMDK:21447054 pagePK:141137 piPK:141127 theSitePK:322341,0 $\underline{0 . h t m l}$

, (2009) "Lebanon: Social Impact Analysis - Electricity and Water Sectors," Social and Economic Development Group, Middle East and North Africa Region, Report No. 48993-LB.

, (2008) "Republic of Lebanon: Electricity Sector Public Expenditure Review," Sustainable Development Department, Middle East and North Africa Region, Report No. 41421-LB.

United Nations Development Programme, (2008) "Poverty, Growth, and Income Distribution in Lebanon," International Poverty Center, Country Study, Number 13.

Weigand, C. and Grosh, M., (2008) "Levels and Patterns of Safety Net Spending in Developing and Transition Countries," SP Discussion Paper, No. 0817, Social Protection and Labor, The World Bank. 